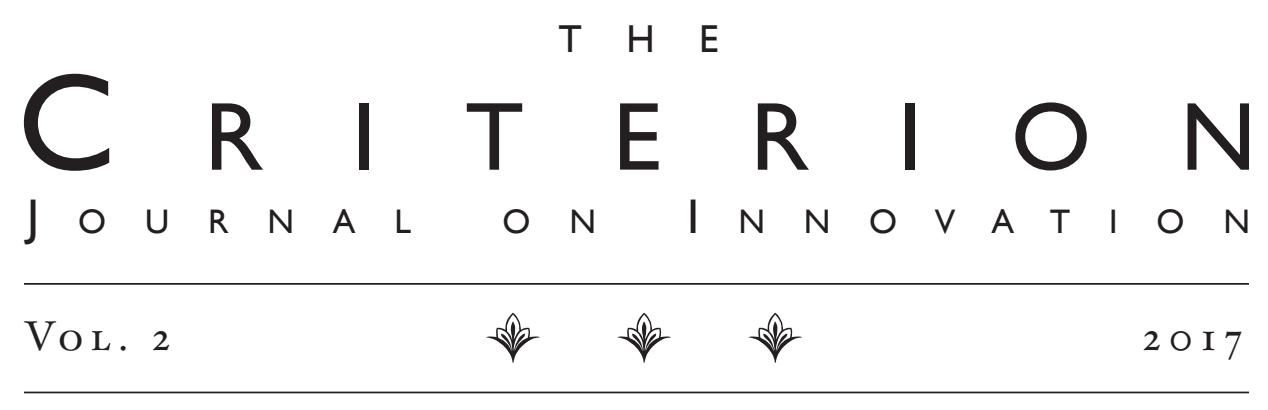

\title{
Patent Tigers: The New Geography of Global Innovation
}

Fonathan M. Barnett ${ }^{*}$

It is widely argued that international extension of the patent system hinders innovation and growth in developing countries by restricting access to technological inputs. I re-examine the connection between patents, innovation, and development by assessing the extent to which the U.S. patent regime supports R\&D investment by firms in emerging market countries. Based on U.S. Patent and Trademark Office (USPTO) data covering all utility patents issued to U.S. and foreign inventors from 1965 to 2015 , and supplemented by additional data sources, I argue that the U.S. patent system has supported innovation in a cluster of foreign countries that have developed dramatically since the I980s. Three smaller and late-developing countries are now (together with Japan) the most intensive foreign users of the U.S. patent system on a per capita and per GDP basis: Israel, South Korea, and Taiwan. Based on entity type, industry type, and other salient characteristics of the leading "first-named" assignees of USPTO patents in Israel and Taiwan from 2000 to 2015 , and supplemented by other evidence concerning these countries' innovation capacities and performance, these countries apparently rely on USPTO patents to extract value from R\&D investments by supplying product or process inputs to the global value chains that connect innovation sources with commercialization sources on the pathway to target consumption markets. Although it is recognized that patents can promote

* Professor, University of Southern California, School of Law. Email: jbarnett@law.usc.edu. I am grateful for comments received at conferences of the American Law \& Economics Association, the Israel Law \& Economics Association, the Society for Institutional and Organizational Economics, and the Western Economics Association International, and presentations at the Intellectual Property Scholars Conference, the Summer Institute of the Center for the Protection of Intellectual Property, the University of San Diego School of Law and the USC Center for Law and Social Sciences. I thank Vanand Baroni, Justin Bongco, Viet Nguyen, and Paul Watanabe for exceptional research assistance. This project has been supported by a grant from the Leonardo Da Vinci Fellowship at the Center for the Protection of Intellectual Property at George Mason University, Antonin Scalia Law School. Copyright 2017 by the Author. All rights reserved. 
entry by upstream R\&D firms that lack downstream production and distribution capacities, this article extends that rationale and presents evidence that patents can promote entry into global technology markets by economies that are rich in intellectual and human capital but have limited domestic markets in which to extract returns on that capital. For those countries, the patent system (or at least the U.S. patent system) is an aid, not a hindrance, to development.

Legal, economic, and policy commentary on the international expansion of the patent system has widely adopted a narrative in which developed countries have "compelled" the rest of the world to unwisely adopt excessively strong patent regimes. ${ }^{\mathrm{I}}$ However, empirical studies support some positive relationship between patent protection, innovation, and economic growth, although the extent of that relationship is far from settled. ${ }^{2}$ In this article, I re-examine this popular narrative by switching the point of reference. I empirically examine the extent to which the patent regime in the United States has supported innovation in certain foreign countries that have rapidly moved from emerging to "late-developing" tiers on the development ladder. More specifically, I examine how U.S. patents support global value chains in which suppliers of $R \& D$ and commercialization inputs interact to deliver technology-intensive goods and services to intermediate and end users in target consumption markets. This inquiry illustrates how the U.S. patent system operates as a de facto world patent system that has enabled a cluster of smaller and late-developing economies that are rich in intellectual capital but have limited domestic markets to supply global supply chains

${ }^{1}$ For representative examples, see Joseph E. Stiglitz, Making Globalization Work iI6-I7 (W.W. Norton \& Co. 2006); Joseph E. Stiglitz \& Andrew Charlton, Fair Trade for All: How Trade Can Promote Development io3 (Oxford Univ. Press 2005); Susan Sell, Private Power, Public Law: The Globalization of Intellectual Property Rights io8-o9 (Cambridge Univ. Press 2003); Peter Drahos \& John Braithwaite, Information Feudalism: Who Owns the Knowledge Economy? 133-37 (Earthscan 2002); Jagdish Bhagwati, Free Trade Today $75-76$ (Princeton Univ. Press 2002); Michele Boldrin \& David K. Levine, The Case Against Patents, 27 J. Econ. Persp. 3, I9 (2013); Neil Weinstock Netanel, Introduction: The WIPO Development Agenda and Its Development Policy Context, in THE Development Agenda: Global Intellectual Property and Developing Countries i, 2-3 (Neil Weinstock Netanel ed., Oxford Univ. Press 2009); Amy Kapczynski, The Access to Knoweledge Mobilization and the New Politics of Intellectual Property, II7 Yale L.J. 804, 824-27 (2008); Jerome H. Reichman \& Rochelle Cooper Dreyfuss, Harmonization Without Consensus: Critical Reflections on Drafting a Substantive Patent Law Treaty, 57 Duke L.J. 85, 94-99, I03-08 (2007); Peter K. Yu, TRIPs and Its Discontents, Io MARQ. Intell. Prop. L. Rev. 369, 38I-86 (2005); Rochelle Cooper Dreyfuss, TRIPS-Round II: Should Users Strike Back?, 7I U. CHI. L. Rev. 2I, 29-30 (2004). For an exception to this skeptical consensus, see Daniel J. Hemel \& Lisa Larrimore Ouellette, Knowledge Goods and Nation-States, IOI MinN. L. Rev. I67, I78-81 (2016) (arguing that international IP treaties solve the global free-rider problem in which nation-states subsidize knowledge production at globally suboptimal levels).

2 For reviews of the empirical literature, see Stephen Haber, Patents and the Wealth of Nations, 23 Geo. Mason L. Rev. 8II, 825-30 (20I6); Maureen K. Ohlhausen, Patent Rights in a Climate of Intellectual Property Skepticism, 30 Harv. J.L. \& Tech. I, 2I-32 (2016); Jonathan M. Barnett, Do Patents Matter? Empirical Evidence on the Incentive Thesis, in Handbook on Law, InNovation and Growth i78, I9I-92 (Robert E. Litan ed., Edward Elgar 20II); Daniel Gervais, TRIPS and Development, in Intellectual Property, Trade and Development: Strategies to Optimize Economic Development in a TRIPS-Plus Era 95-II2 (Daniel Gervais ed., Oxford Univ. Press 2007). 
with product and process innovations. Consistent with standard economic theories of national comparative advantage, the result is a presumptively efficient global allocation of innovation, production, and distribution functions, resting in significant part on the legal infrastructure supplied by the U.S. patent system. Contrary to the standard narrative, the patent system-or specifically, the U.S. patent system-appears to have helped, not harmed, at least some countries that have achieved significant movement up the development ladder.

I start by using USPTO data from a fifty-year period, from 1965 to 2015 , to identify historical trends in patenting activity by foreign inventors. The dataset comprises 6,122,194 utility patents issued to inventors resident in I88 countries and territories (including the United States). Since approximately the late 1990 s, there has been a dramatic and continuing surge in patent issuances to foreign inventors in general and, in particular, inventors resident in East Asian countries. Foreign inventors now constitute a slight majority of all patent applicants and grantees at the USPTO and East Asian inventors now outnumber inventors resident in any region outside North America. Within the population of high-performing foreign inventors, three countries are exceptional: Israel, Korea, and Taiwan. All three countries-which I call the "patent tigers"-exhibit rates of patent issuance, whether measured on a per capita or per GDP basis, that dramatically exceed all countries in recent years except the United States and Japan. To address the concern that these countries may be "patent factories" rather than productive sources of innovation inputs, I use various measures to assess each patent tiger's innovative capacities and performance. First, I assess each patent tiger's "success ratio" in the USPTO examination process, which, subject to certain methodological complications, provides some insight into the quality of a country's applications. Relatedly, I survey existing data on the citation rates of USPTO patents issued to inventors from these countries. Second, I review existing data relating to other commonly used measures of innovative performance, such as investment in higher education, per capita $R \& D$ personnel, $R \& D$ as a percentage of GDP, and the technology balance of payments. Each of the patent tigers scores highly (and sometimes exceptionally highly) on most of these measures, which mitigates the "patent factory" concern.

It remains to consider why the tiger countries invest so heavily in the acquisition of USPTO patents. I argue that these countries' high-intensity patenting strategies mitigate a common transactional dilemma. The tiger countries have relatively small domestic markets and therefore can only maximize returns on their human and intellectual capital investments through sales of technology inputs, or products or services that incorporate technology inputs, to larger foreign markets. But the pathway to those rich consumption markets is encumbered by expropriation risks that are peculiar 
to commercial relationships involving informational assets. Patents ameliorate the expropriation risk inherent in exchanging information between a firm that holds an innovation input and third parties that hold the complementary inputs required to support commercialization in target markets. Existing theory and empirics suggest that patents often enable smaller upstream $\mathrm{R} \& \mathrm{D}$-intensive firms to transact safely with larger production and distribution partners located downstream on the supply chain. ${ }^{3}$ That same rationale can be applied at the country level: that is, patents enable smaller $\mathrm{R} \& \mathrm{D}$-intensive countries to transact safely with countries that excel in the production and distribution capacities required to reach market. The result is a classic case of comparative advantage, resulting in a presumptively efficient division of tasks among specialized providers situated along a disaggregated commercialization pipeline.

I explore most closely the proposed link between patents, transactional hazards, and comparative advantage through case studies of two patent tigers, Israel and Taiwan. ${ }^{4}$ To undertake this inquiry, I use USPTO and other data to identify the leading Israeli and Taiwanese users of the USPTO system as well as those firms' positions on the technology supply chain. Based on this data, and supplemented by existing evidence, I argue that the USPTO system supports knowledge exchanges that are critical to each country's ability to monetize its R\&D investments in global technology supply chains. In the case of Israel, patents primarily enable upstream entities to monetize $\mathrm{R} \& \mathrm{D}$ investments through licensing, corporate-control, and other transactions with foreign integrated firms. This applies to three important categories of Israeli patentees: (I) academic research institutions; (2) the R\&D affiliates of leading foreign technology firms (typically established or expanded through the acquisition of local startups); and (3) local technology firms in the information technology and life sciences markets. In the case of Taiwan, the patenting data reflect an innovation economy consisting primarily of

3 For key references, see Jonathan M. Barnett, Intellectual Property as a Law of Organization, 84 S. CAL. L. Rev. 785 (20II); Paul J. Heald, A Transaction Costs Theory of Patent Law, 66 OHIo St. L.J. 473 (2005); Robert P. Merges, A Transactional View of Property Rights, io Berkeley Tech. L.J. I477 (2005); Ashish Arora \& Robert P. Merges, Specialized Supply Firms, Property Rights and Firm Boundaries, I3 INDUs. \& CoRP. Change 45I, 472 (2004).

4 Israel's intensive patenting activities at the USPTO appear to have been first addressed in detail by Manuel Trajtenberg, along with some discussion of USPTO patenting by Korea and Taiwan. See Manuel Trajtenberg, R\&D Policy in Israel: An Overview and Reassessment (NBER Working Paper No. 7930, 200o); Manuel Trajtenberg, Innovation in Israel 1968-1997: A Comparative Analysis Using Patent Data (NBER Working Paper No. 7022, I999). My study extends that data through 2015, supplements detailed study of Taiwan, updates detailed study of Israel, and accounts for Israel's, Korea's, and Taiwan's intensive patenting as a response to a common set of transactional hazards. Based primarily on qualitative observations, AnnaLee Saxenian discusses the prominence of Israel and Taiwan (mostly the latter) in the global technology marketplace. See Annalee Saxenian, The New Argonauts: Regional Advantage in a Global Economy i22-96 (Harvard Univ. Press 2006). She attributes these countries' achievements in large part to the international circulation of human capital, whereas my account emphasizes the role of patent rights and contractual agreements in regulating the exchange of knowledge assets between these countries and foreign partners in the commercialization pipeline. 
three entity types: (I) a government-sponsored applied research institute that develops technologies for licensing to the private sector; (2) "foundries" that develop process innovations in chip production for the semiconductor market; and (3) chip design firms that contract with the foundries for production services. As in Israel, the research institute and chip design firms are upstream innovation entities that rely on patents to monetize their $\mathrm{R} \& \mathrm{D}$ investments through transactions with downstream production and distribution partners. Taiwan's foundries are "mid-stream" entities that use patents to extract returns on their R\&D investments in developing production technologies for chip design firms.

Organization is as follows. In Part I, I present data relating to historical changes in foreign patenting at the USPTO and the exceptional group of patent tigers. In Part II, I present data that addresses whether the tiger countries' patent acquisition activities reflect innovation or opportunism. In Part III, I propose a transactional rationale for the tiger countries' intensive acquisition of U.S. patents. In Part IV, I present case studies of patenting and innovation activities in Israel and Taiwan. I briefly conclude.

\section{The USPTO Goes Global: Patenting Trends (1965 TO 2015)}

In this part, I present evidence relating to trends among residents of foreign countries who apply for patents at the USPTO. I then assess whether those patenting trends are indicative of innovation activities in those foreign countries. The time period is generally 1965 to 2015 , although in some cases I study shorter periods due to data availability. 5

\section{A. Background: The Value of a U.S. Patent}

Unlike the existing empirical literature, I address the relationship between patenting and innovation by examining the relationship between U.S. patent protection and foreign innovation. Focusing on a single patent regime avoids the "comparing apples to oranges" problem inherent in comparative studies that must address inconsistencies between patent regimes-both as a matter of law and as a matter of practice-across different countries. However, my approach is only sensible if there were something especially attractive about the U.S. patent system from the perspective of a foreign inventor. This assumption appears to be reasonable based on observed market behavior: as of 20I4, foreign applications at the USPTO constituted a significantly larger

5 Two methodological notes apply throughout. First, all data relate solely to utility patents (that is, not design patents or plant patents) and, unless otherwise indicated, are based on data available through the USPTO. Second, I follow the USPTO's practice of determining the applicant's or grantee's nationality based on the stated residence of the first-named inventor in the patent application. 
percentage of total applications as compared with any other large patent office. ${ }^{6}$ Data compiled by the World Intellectual Property Organization show that (as of 2009), if an inventor files a patent in his or her home country's office and then seeks patent protection in a foreign country, the USPTO is the most popular subsequent destination. ${ }^{7}$ There are three principal reasons why foreign inventors might find a USPTO patent especially attractive. ${ }^{8}$

\section{Large Consumer Market}

The United States is the world's largest consumer market, representing 26.7 percent of world household consumption as of $2015 .{ }^{9}$ That statistic understates the attraction of the U.S. market because the United States provides firms not only with the largest consumer market, as measured by sales, but also with a population that enjoys among the world's highest per capita income levels,$^{\mathrm{IO}}$ thereby allowing firms to enjoy larger profit margins as compared with countries in which consumers are subject to tighter budget constraints.

\section{Administrative Fees}

When compared with other jurisdictions, the United States offers patent applicants greater market coverage per dollar spent on filing fees, maintenance fees (to avoid lapse of the patent term), and legal fees. Relative to the European Union, the United States offers a foreign inventor lower filing fees and greater administrative convenience because its market can be accessed through a single filing, rather than through the multiple national filings required in the European Union. ${ }^{\text {II }}$ To achieve and maintain coverage for a

6 See European Patent Office, Japan Patent Office, State Intellectual Property Office of the People's Republic of China, Korean Intellectual Property Office \& United States Patent and Trademark Office, IP5 Statistics Report (2OI4), http://www.fiveipoffices.org/statistics/statisticsreports/2OI4edition/ip5sr2OI4.pdf.

7 See id. at 54 .

8 I note that there is some empirical evidence suggesting that foreign patent holders may fare less well in U.S. infringement litigation than U.S. patent holders when the case is decided by jury. See Kimberly Moore, Xenophobia in American Courts, 97 N.W. L. Rev. 1497 (2003) (based on samples consisting of all patents granted during I990 to I999 and all patent cases that concluded during I999 to 2000). However, based on observed market behavior, any such bias has apparently failed to discourage foreign investors from investing significant resources in applying for U.S. patents.

9 World Bank, Household Final Consumption Expenditure (Constant 20IO US\$), http://data.worldbank.org/indicator/NE.CON.PRVT.KD.

10 Based on World Bank data, the United States was ranked thirteenth in per capita GDP as of 2015 (on a purchasing power parity basis). Except for Switzerland and Ireland, all higher-ranked countries are small "petro" states or "city-state" jurisdictions. See World Bank, International Comparison Program Database, GDP Per Capita, PPP, http://data.worldbank.org/indicator/NY.GDP.PCAP.PP.CD?end=2015\&start=2015.

11 Although this burden is mitigated somewhat by the implementation of the European Patent Office, which enables a patentee to access all member countries through a single patent application, there are still country-specific validation, translation, and renewal fees. See European Commission, Patent Costs and ImpaCt on InNovation: International Comparison and ANalysis of the ImpaCt on the Exploitation of R\&D Results by SMEs, Universities and Public Research Organisations 8 (20i4), 
single patent for the full 20 -year term in the six most popular European filing jurisdictions (representing 67 percent of the total economic output of the European Union), an inventor must incur fees almost six times greater than the fees that would be incurred at the USPTO. ${ }^{\text {I2 }}$

\section{Enforcement Infrastructure}

The United States provides patent holders with a comparatively robust enforcement infrastructure. In particular, a USPTO patent offers a more attractive enforcement alternative than two other comparably sized markets: China and the European Union. In the first case, the enforcement difficulties are well known, even taking into account reported improvements in recent years. ${ }^{13}$ In the second case, the European Union raises enforcement obstacles that do not exist in the United States, because there is doubt whether injunctions issued by a court in one EU member country will be honored by other member countries. ${ }^{14}$ By contrast, in the United States, there is no such issue given that U.S. patent law operates as a unitary federal regime. Additionally, the United States has an especially effective enforcement venue for patent holders seeking to block the importation of infringing goods into the United States. Patentees can seek redress at the International Trade Commission (ITC) to obtain an exclusion order that instructs U.S. customs to block importation of the infringing product. ${ }^{15}$ ITC proceedings typically last 15 to I8 months until relief, which is significantly faster than a patent infringement litigation in federal court ${ }^{16}$ (where median time to trial is approximately 2.4 years $^{17}$ ) and, unlike a plaintiff in a federal district court action, the patentee can secure a general exclusion order that applies broadly to an

http://www.oepm.es/export/sites/oepm/comun/documentos_relacionados/Publicaciones/Estudios-Articulos/20I6_I2_I9_Costes_de_patentes_y_su_impacto_en_innovacion.pdf.

12 See id. at $2 \mathrm{I}$.

13 For a recent account, see Michael B.G. Froman, Office of the United States Trade RepreSENTATIVE, 2OI4 SPECial 3OI RePORT 35-37 (2OI4), https://ustr.gov/sites/default/files/USTR\%2O2OI4\%2O Special\%20301\%20Report\%20to\%20Congress\%2OFINAL.pdf.

${ }_{14}$ See Stuart J.H. Graham \& Nicolas van Zeebroeck, Comparing Patent Litigation Across Europe: A First Look, i7 Stan. Tech. L. Rev. 655, 674, 678-80 (2014).

15 i9 U.S.C. \$ 1337.

16 See H. Mark Lyon \& Sarah E. Piepmeier, ITC Section 337 Investigations: Patent Infringement Claims (20I2), http://www.gibsondunn.com/publications/Documents/Lyon-ITCSection337InvestigationsPatentInfingementClaims.pdf.

17 Price WaterhouseCoopers, 2015 Patent Litigation Study: A Change in Patentee Fortunes i4 (2015), https://www.pwc.com/us/en/forensic-services/publications/assets/2015-pwc-patent-litigation-study. pdf. 
entire class of goods. ${ }^{18}$ Critically, the Federal Circuit has held ${ }^{19}$ that the ITC, as an administrative agency, is not bound by eBay, Inc. v. MercExchange LLC, ${ }^{20}$ a Supreme Court precedent that has significantly limited the circumstances in which an injunction is a realistically available remedy in patent infringement litigation. ${ }^{21}$

\section{B. Rise of Foreign Inventors}

As measured by changes in absolute figures for patent grants, there has been a significant increase in the percentage of non-U.S. patent grantees from 1965 to 2015 , starting in particular in the early 1980 s. In 1965, non-U.S. patent grantees constituted 20 percent of total grantees. ${ }^{22}$ By 2008 , non-U.S. patent grantees constituted a majority of total grantees, and, in 2015 , non-U.S. residents constituted 53 percent of all grantees. ${ }^{23}$ The same trends are true of patent applications. By 2009 , non-U.S. patent applicants constituted a majority of total applicants and, in 2015, they constituted 51 percent of all applicants. ${ }^{24}$ Clearly the USPTO has become the world's patent office.

18 This is because the ITC exercises in rem jurisdiction over the allegedly infringing imports. See Russell E. Levine, The Benefits of Using the ITC, Managing Intell. Prop., Sept. 2004. However, the plaintiff must show that there is a U.S. industry relating to the "article" protected by the patent (the domestic industry requirement). See I9 U.S.C. \$ $1337(\mathrm{a})(2)-(3)$. Although uncertainty remains, courts have sometimes interpreted this requirement generously, concluding that it has been satisfied by foreign entities solely engaged in patent licensing in the U.S. or foreign entities with a U.S. subsidiary engaged in engineering support. See Certain Semiconductor Chips with Minimized Chip Package Size and Products Containing Same, Inv. No. 337-TA-432, 200I WL I426690, at ${ }^{*} 52$, 60 (Sept. 25, 200I); Certain Integrated Circuits, Processes for Making Same and Products Containing Same, Inv. No. 337-TA-45o, at 247-75, 277 (May 6, 2002)

19 Spansion, Inc. v. ITC, 629 F.3d I331, I358-59 (Fed. Cir. 2010).

20547 U.S. 388 (2006).

21 See Christopher B. Seaman, Permanent Injunctions in Patent Litigation After eBay: An Empirical Study, IOI Iowa L. Rev. I949 (2016).

22 Author's calculations, based on United States Patent and Trademark Office [USPTO], Extended Year Set-All Technologies (Utility Patents) Report pt. AI, tbl.AI-Ia, https://www.uspto.gov/web/offices/ac/ido/ oeip/taf/h_at.htm (last visited February 15, 20I7) [hereinafter USPTO, Utility Patents Report].

23 Author's calculations, based on USPTO, Utility Patents Report, supra note 22.

24 Author's calculations, based on USPTO, Utility Patents Report, supra note 22. 
Figure I. U.S. and Non-U.S. Recipients of

USPTO Utility Patents (1965 to 2015)

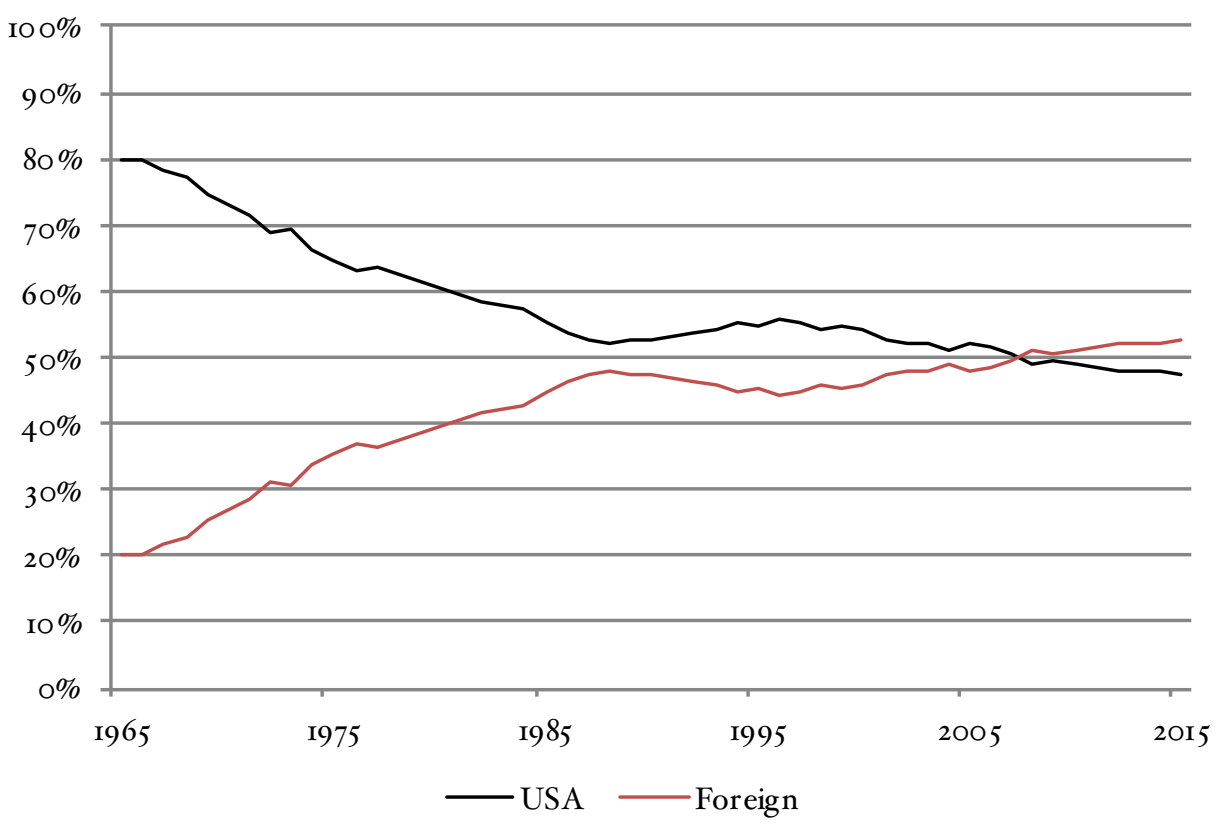

Source: USPTO, Utility Patents Report, supra note 22.

\section{Rise of East Asian Inventors}

If we break up the world into four principal regions (North America, Europe, East Asia, and "Rest of World"), we can observe which regions have exhibited increasing, constant, or declining "market share" in patent grants at the USPTO. All countries and territories for which the USPTO provides grant data from 1965 to 2015 were placed into four categories: (I) North America; (2) Europe; (3) East Asia; and (4) "Rest of World." North America refers to Canada, Mexico and the United States; ${ }^{25}$ Europe refers to all countries that are principally located on the European continent; ${ }^{26}$ East Asia refers to the People's Republic of China (including Hong Kong and Macau), Japan, North

25 The overwhelming majority of patents awarded to North American applicants are awarded to U.S. applicants. In 2015, U.S. applicants received 140,969 patents, representing more than 95 percent of all North American patent grants; Canadian applicants received 6,802 patents, representing 4.6 percent; and Mexican applicants received 172 patents, representing less than I percent. Author's calculations, based on USPTO, Utility Patents Report, supra note 22.

26 This excludes Turkey, the U.S.S.R., and all former members of the U.S.S.R. (including the Russian Federation), except Estonia, Latvia, Lithuania, and Moldova. Hence, the number of countries included in the "Europe" region increases slightly after the dissolution of the Soviet Union in the early I990s. Because these four additional European countries are not significant recipients of USPTO patents, this is unlikely to affect regional percentages to any material extent. 
Korea, Singapore, South Korea, and Taiwan. "Rest of World" refers to all other countries.

North America has held the largest but a declining share of total patent applicants and grants, and Europe has maintained a smaller but significant share, whereas East Asia has achieved dramatic growth from a baseline of almost no USPTO patenting activity. In 1990, East Asia overtook Europe as the second-largest regional recipient of U.S. patents and has steadily increased its market share. More specifically, if we look at the end points of the time range shown below (1965 and 2015), North America's share of total grants has declined from 83 percent to 50 percent; Europe's share has held constant at slightly more than 15 percent (after a surge past 20 percent during the late I970s and 1980s); and East Asia has experienced a dramatic increase from I percent in 1965 to $3 \mathrm{I}$ percent in 2015. The rest of the world (with the exception, to be discussed, of Israel and, to a lesser extent, India) has not experienced any material change in its relative percentage of total patents issued. Clearly there has been a shift in the relative share of patenting volume at the USPTO toward East Asia and away from North America.

Figure 2. USPTO Utility Patents on a

Regional Basis (1965 to 2015)

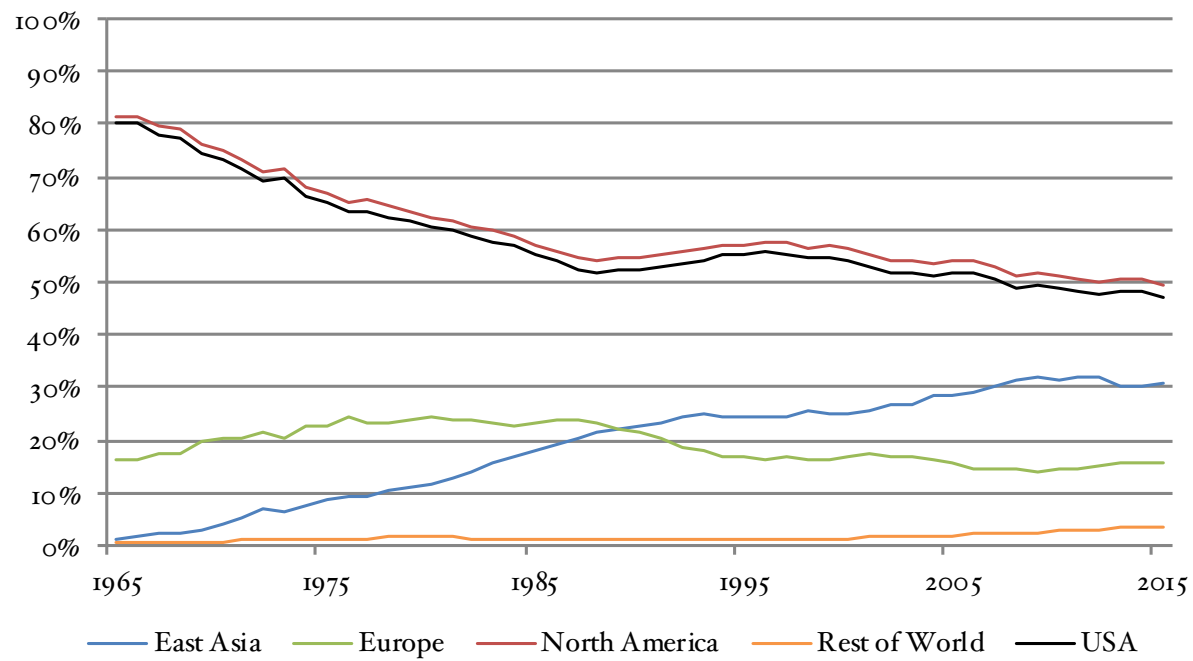

Source: Author's calculations, based on USPTO, Utility Patents Report, supra note 22, pt. Ar. For regional classifications, see supra text accompanying notes $25-26$. 
2017] Patent Tigers

\section{Patent Tigers}

I will now move below the regional level of analysis and identify specific countries that are particularly intensive users of the patent system. For this purpose, I use three alternative measures of USPTO patenting activity: (I) absolute numbers of patent grants; (2) patent grants per capita; and (3) patent grants per gross domestic product (GDP). The per capita and per GDP measures yield a comparable ranking of countries but deviate significantly from the ranking derived using absolute measures of patent grants. In particular, these two measures identify a group of three smaller and "late-developing" countries-namely, Israel, Korea, and Taiwan-that outperform almost every other country outside the United States in terms of USPTO patenting activity, starting in the early to mid-20oos through the present. For purposes of all three measures below (absolute, per capita, and per GDP), I only assessed the 22 countries that had received at least IO,000 patents in total from 1965 to $2015 .{ }^{27}$ I refer to these 22 countries as the "selected countries."

\section{Absolute Patenting Rates}

Figure 3 below shows historical changes in the number of patents granted annually to residents of the 15 countries that were issued the largest number of patents in 2015. "China Combined" refers to patents granted to residents of the People's Republic of China, Hong Kong, and Macau, which I will refer to collectively as "China." By this absolute measure, the United States and (to a significantly lesser extent) Japan are the most intensive users of the USPTO. Both the United States and Japan exhibit increasing absolute grant rates starting in the mid-I980s and then increasing sharply through the I990s and 2000 .

27 For purposes of this calculation, I treated the U.S.S.R. and the Russian Federation as a single entity. Based on that assumption, the combined entity crosses the Io,ooo patent threshold for this period. Note also that the USPTO data credits to "Germany" the patents granted to East and West Germany. The selected countries are (in declining order of total patents granted from 1965 to 2015): the United States, Japan, Germany, the United Kingdom, Korea, France, Taiwan, Canada, Switzerland, Italy, Sweden, the Netherlands, China Combined, Israel, Australia, Belgium, Finland, Austria, India, Denmark, Spain, and Russia or the U.S.S.R. 
Figure 3. Top I5 USPTO Grantee

Countries (1965 to 2015)

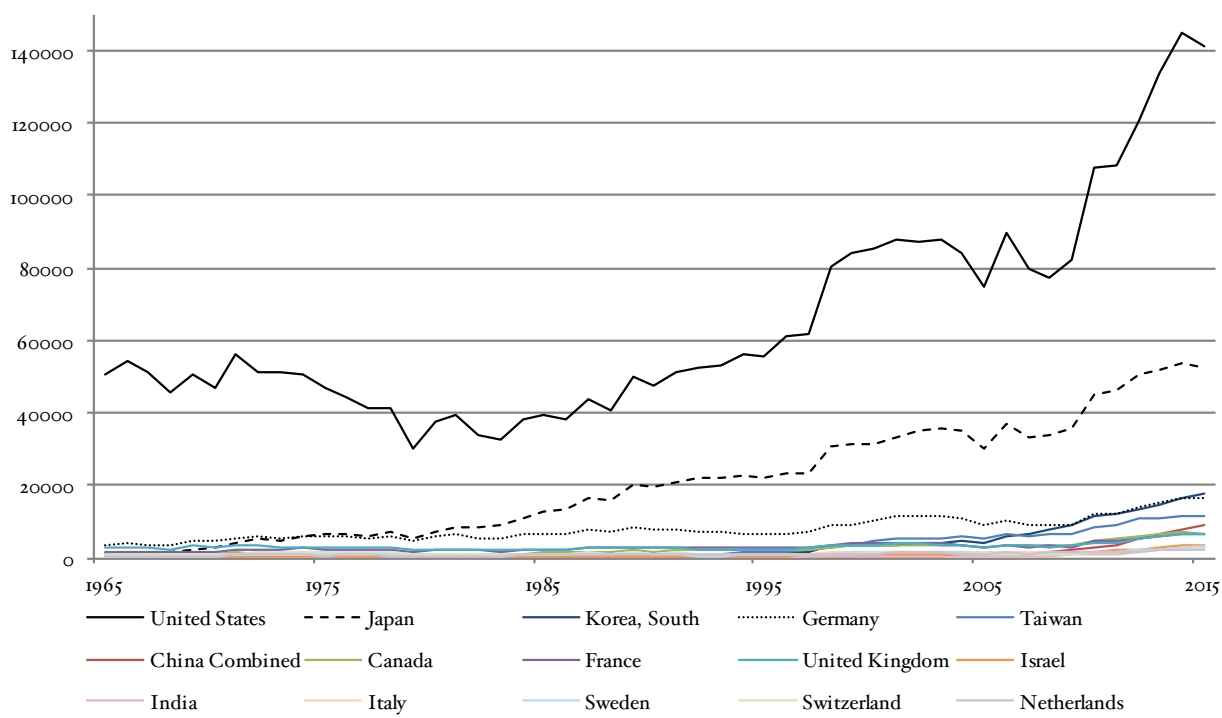

Source: USPTO, Utility Patents Report, supra note 22, pt. Ar.

Note: Countries appear in the legend based on their ranking in terms of patents issued in 2015 (starting from the United States and moving to the right).

If we remove the two patenting leaders, the United States and Japan, we can observe the sharp increases in patenting rates starting in the late $1990 \mathrm{os}$, measured in absolute terms, with respect to Taiwan and Korea, with the latter overtaking Germany in 2015. Remarkably, Taiwan now substantially exceeds the patenting rates of larger countries such as France and the United Kingdom, which had occupied the third and fourth positions in USPTO patenting rates in 1965 . 
Figure 4. Top 15 USPTO Grantee Countries

(1965 to 2015), Ex-United States and Japan

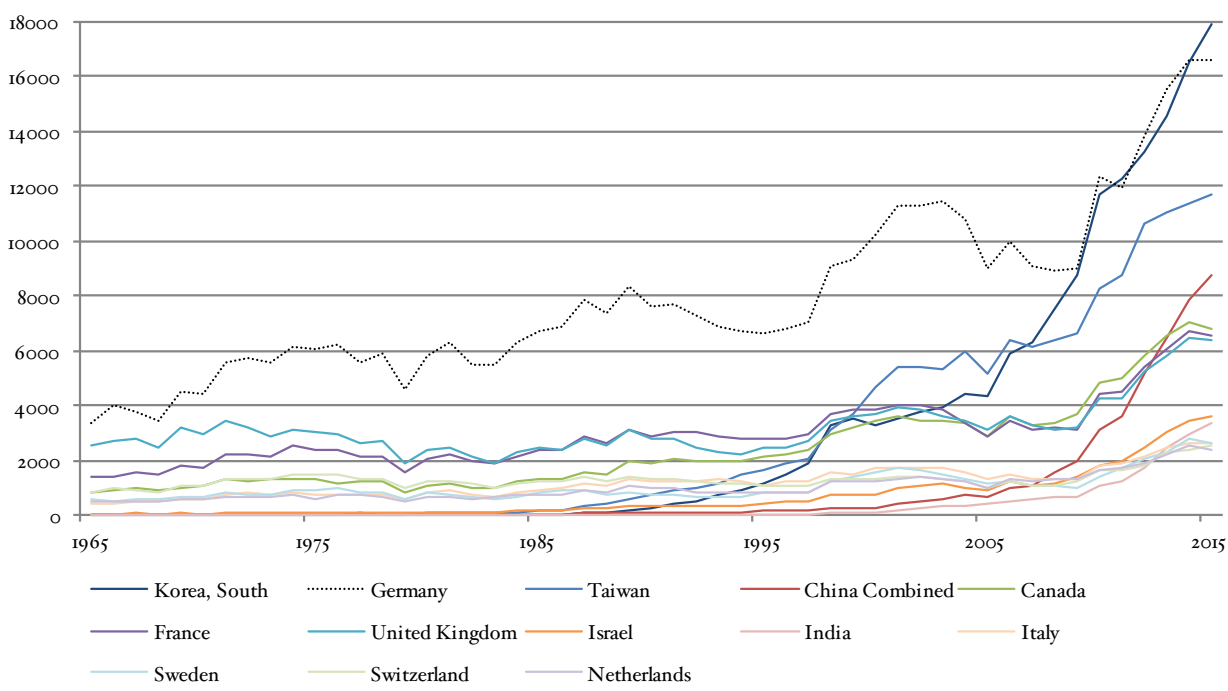

Source: USPTO, Utility Patents Report, supra note 22, pt. AI.

Note: Countries appear in the legend based on their ranking in terms of patents issued in 2015 (starting from Korea and moving to the right).

\section{Per Capita Patenting Rates}

To better compare patenting activities across countries irrespective of the size of a country's population, I determined the per capita patent grant rates for the selected countries. ${ }^{28}$ Below, I show the changes in annual per capita patent grant rates for the selected countries with the 15 highest per capita patent grant rates in $2015 .{ }^{29}$ Per capita is defined as per I million resident population.

28 All per capita figures were calculated based on (I) USPTO data for patent grants and (2) estimated national population figures from the U.S. Census Bureau. See U.S. Census Bureau, International Data Base, http://www.census.gov/population/international/data-tools/demo/idb/informationGateway.php (last visited July 2015). I extracted data on each country's estimated population at five-year intervals (starting in 1965 ) and assumed an equal annual rate of growth between the start and end year of each interval. I calculated country-specific annual per capita patenting figures and then, based on each country's regional attribution, consolidated those figures to calculate regional annual per capita patenting rates. For an explanation of each country's regional attribution, see supra notes $25-26$ and accompanying text. Note that, in the case of Germany, the Census Bureau consolidates population data for East and West Germany as if the two countries were a single country throughout the period above. Author communication with Demographic and Economic Studies Branch, Population Division, U.S. Census Bureau (July 5, 2016).

29 For details on methodology, see supra note 5 and accompanying text. Note that Singapore and Norway place among the top 15 countries on a per capita patenting basis for 2015 (twelfth and fifteenth, respectively); however, they are not included in the group above because they do not qualify as a "selected country" (that is, they did not accumulate at least I0,000 patents from 1965 to 2015). 
Figure 5. Top I5 USPTO Grantee Countries

(Per I Million Population) (I965 to 2015)

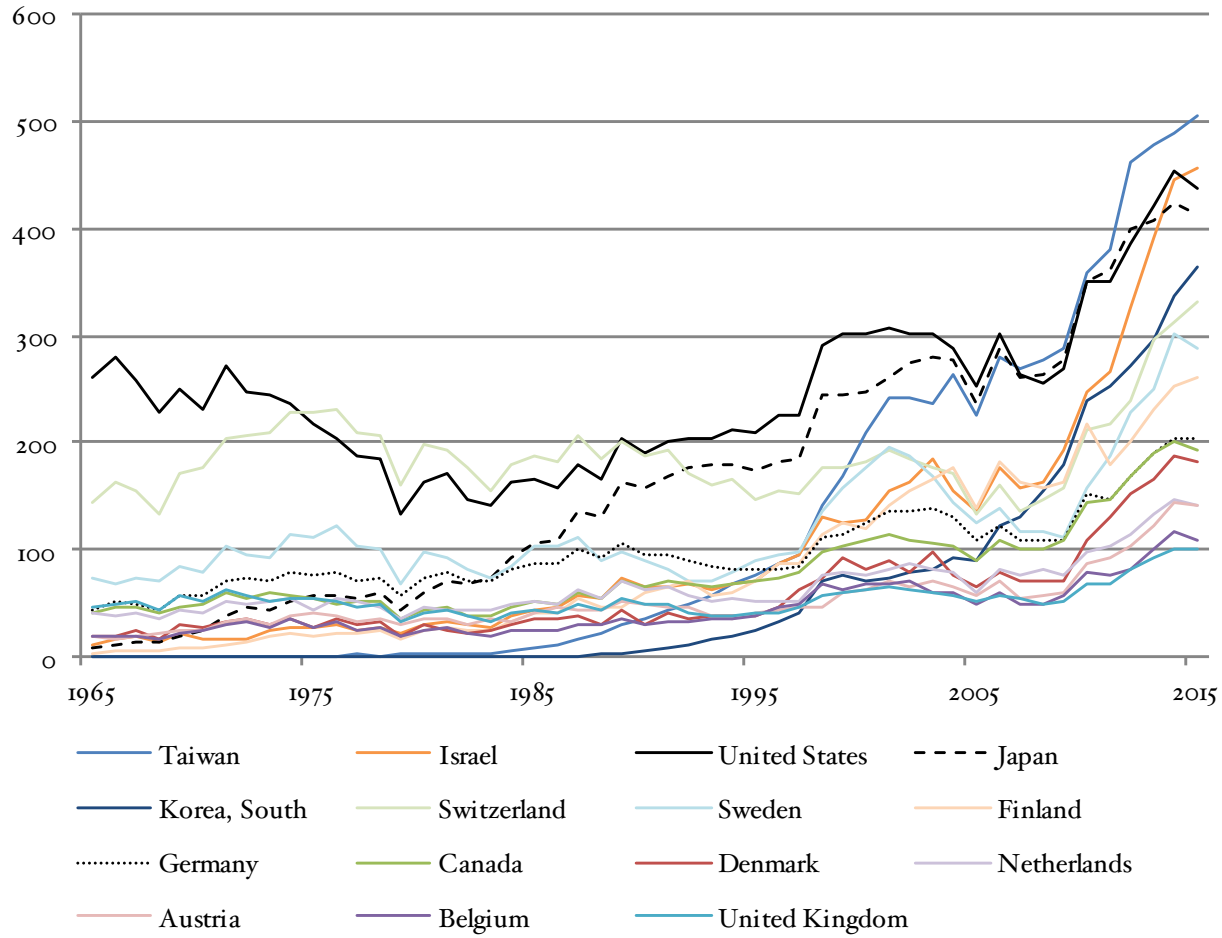

Sources: Author's calculations, based on USPTO, Utility Patents Report, supra note 22; U.S. Census Bureau, International Data Base, supra note 28.

Note: Countries appear in the legend corresponding to their ranking in terms of per capita patent grants in 2015 (starting with Taiwan and moving to the right).

The graph supports several interesting observations. First, use of the per capita measure provides a more insightful sorting of high-patenting and low-patenting countries. In particular, use of the per capita measure eliminates three large countries that had appeared as leaders when assessed on an absolute basis: Italy, France, and China Combined, which are replaced by four smaller countries: Finland, Denmark, Belgium, and Austria. Additionally, a larger, developed country, the United Kingdom, moves down to last, while other smaller and late-developing countries move up (most notably, Taiwan and Israel, which are now the first- and second-place countries in patenting rates, as measured on a per capita basis).

Second, all countries in the group have shown increased per capita patent grant rates as compared with 1965 . As of 1965 , only two countries, the United States and Switzerland, had per capita patenting rates in excess of Ioo patents per I million population; as of 2015 , every country had crossed that threshold. 
Third, the period from 1965 through approximately the mid-I990s is a dormant period of little growth (but no significant decline) in per capita patenting rates for almost all countries. However, in the case of the United States (as previously noted) and, to a lesser extent, Switzerland, this is a period of significant decline in per capita patenting rates starting in the early to mid-I970s. An exception to both trends is Japan and Taiwan, which show a significant increase in patenting rates starting in the late 1980 s and lasting through the present.

Fourth, the period from the late I990s through the present is a period of significant growth in per capita patenting rates for all countries. This period is characterized by two "explosions" in patent issuance. The first commences in the late I990s and, in the case of the United States and Switzerland, represents a return to pre- 1972 patenting levels. Patenting rates then subside approximately in 2004 and a second and steeper increase in patenting rates commences, starting in 2010 .

Fifth, during the two significant increases in patent issuance, there is more heterogeneity in patenting rates across countries as compared with any prior period in the data presented above. As of 2015, per capita patenting rates ranged from slightly more than Ioo per I million population in the case of the United Kingdom to slightly more than 503 in the case of Taiwan. By contrast, as of 1965 , all countries except the United States and Switzerland (later joined by Japan in the mid-I980s) were clustered together at values around or below 50 patents per I million population. More specifically, as of 2015, we can distinguish three groups of countries based on per capita patenting rates. Within each group, countries are listed by descending order of per capita patenting rates. In each case, $x$ denotes the ratio of patents to I million residents as of 2015 .

(I) Group I $(x>400)$ : Taiwan, United States, Israel, Japan.

(2) Group II $(200<x<400)$ : Korea, Switzerland, Sweden, Finland, Germany.

(3) Group III $(x<200)$ : Canada, Denmark, the Netherlands, Austria, Belgium, United Kingdom.

The group I countries, which show the highest per capita patenting rates, consist of two expected members, the United States and Japan, the world's two largest developed economies. Both countries are home to the world's leading firms in two patent-intensive industries-namely, information technology (in the case of Japan and the United States) and biopharmaceuticals (in the case of the United States). Both countries have well-developed science and engineering education systems, rich consumer markets for technology-intensive products and, in the case of the United States, rich capital 
markets to fund the commercialization of technology-intensive products. Some of those same characteristics are true of the group II and group III countries, which are (with the exception of Canada and Korea) Western European countries that have access to rich consumer and capital markets. Canada is in a similar situation insofar as it has easy geographic (and linguistic) access to the rich consumer and capital markets of its neighbor. Korea has a moderately sized consumer market (sixteenth in the world as of 2015, representing 1.46 percent of world household consumption ${ }^{30}$ ) but a relatively undeveloped venture capital market. ${ }^{3 \mathrm{I}}$

Two smaller countries, Israel and Taiwan, appear in group I and do not share these characteristics. Two points are notable about these countries. First, unlike the other members of group I and most members of groups II and III (Korea being the exception), both countries (especially Taiwan) started from extremely low to low rates of patenting, both in absolute and per capita terms, as of the mid-r980s. Even when measured in absolute terms, both of these small countries appear among the top ro recipients of U.S. patents as of 2015 , as noted above. When measured on a per capita basis, these countries move to the top of all countries as of 2015. Israel and Taiwan have become USPTO patenting powerhouses (on a per capita basis and, to a lesser extent, even on an absolute basis) in a remarkably short time. In 1985 , Taiwan had 9 and Israel had 44 patents per I million population; as of 2015 , Taiwan had 504 and Israel had 457 patents per I million population. Second, also unlike the other members of group I (and, if we treat the European market as a single market, all other members of groups II and III, with the partial exception of Korea), Israel and Taiwan do not have rich consumer or capital markets.

\section{Per GDP Patenting Rates}

Another measure that can provide insight into comparative levels of USPTO patenting activity irrespective of population differences is "per GDP" patenting rates, which yield a measure of "patent productivity." ${ }^{2}$ Specifically, I measured each selected country's annual patenting rates per billion dollars of

\footnotetext{
30 World Bank, Household Final Consumption Expenditure (Constant 2010 US\$), http://data.worldbank.org/indicator/NE.CON.PRVT.KD.

31 Organisation for Economic Co-operation and Development [OECD], OECD Economic SURVEYS: KOREA 20I6, at 39-40 (noting limited venture capital for entrepreneurial firms in Korea's "bankcentered" financial system).

32 I borrow the phrase from Richard Gruner, who performs a similar analysis of country-level USPTO patents to GDP ratios but covers a smaller set of countries and shorter time period (specifically, patents issued for applications that were filed between 1977 and 200 I and granted by 2006). See Richard S. Gruner, The World as Our Technologist: Visualizing Worldwide Sources of Technologies Patented in the United States, 2013 U. Ill. J.L. Tech. \& Pol'y 279. Gruner also uses a different patent dataset compiled by the National Bureau of Economic Research, which bases national affiliation on the location of the assignee. By contrast, I rely on USPTO data that bases national affiliation on the residence of the first-named inventor.
} 
that country's annual GDP (in constant 2010 dollars). ${ }^{33}$ For the period I980 to 2015 , the graph shows annual patent productivity for the selected countries with the 15 highest patent productivity scores as of $2015 .{ }^{34}$

Figure 6. Top I5 USPTO Grantee Countries (Per Billion USD GDP) (1980 to 2015)

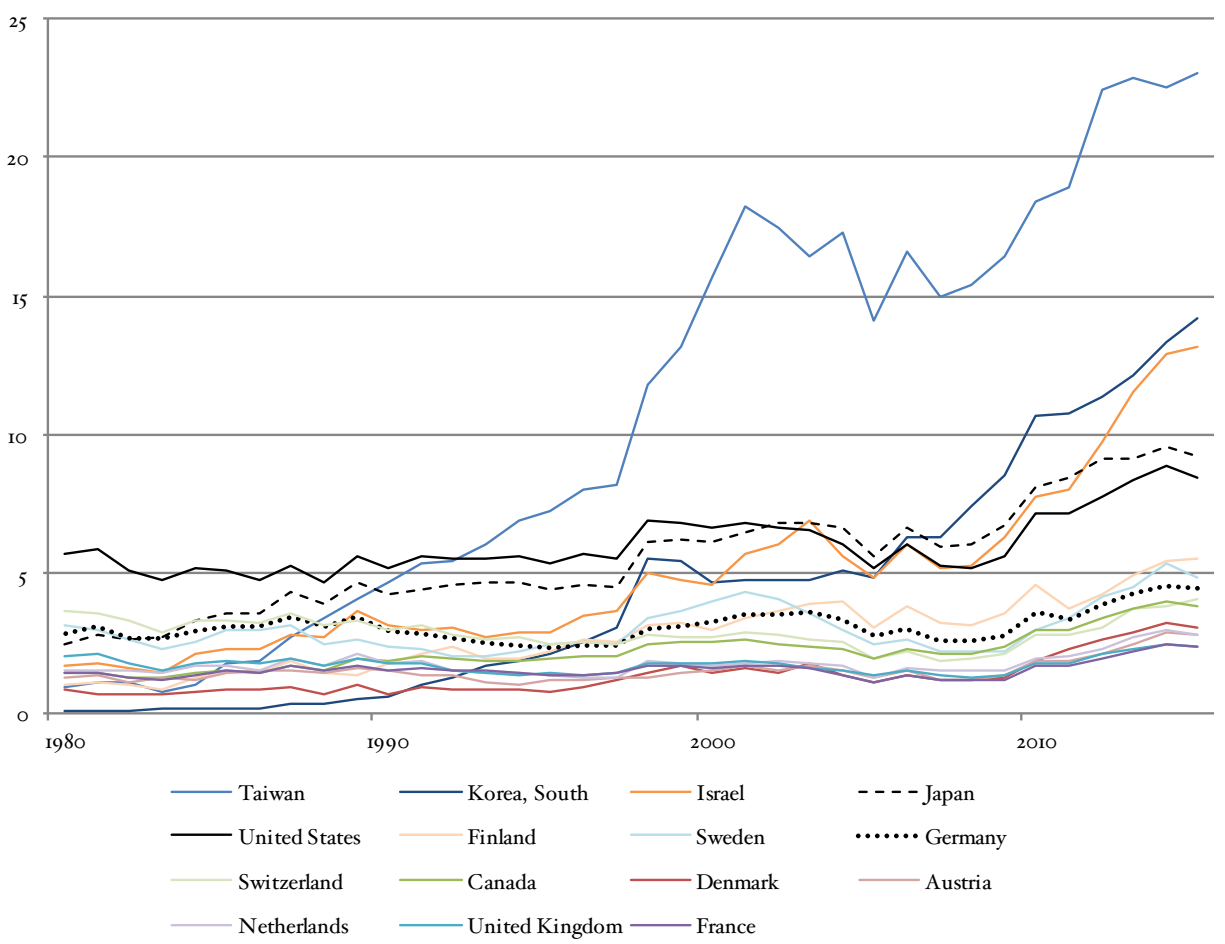

Sources: Author's calculations, based on USPTO, Utility Patents Report, supra note 22; USDA, International Macroeconomic Data Set, supra note 33.

Notes: Countries are listed in the legend in declining order of their utility patent to GDP rate, as of 2015 (starting from Taiwan and moving to the right).

33 All per GDP figures were calculated based on (I) USPTO data for patent grants; and (2) GDP data from the U.S. Department of Agriculture, Economic Research Service, International Macroeconomic Data Set, Real Historical Gross Domestic Product (GDP) and Growth Rates of GDP for Baseline Countries/Regions (in Billions of 2010 Dollars) 1980-2015 (last updated Sept. 21, 2016), http://www.ers.usda.gov/data-products/international-macroeconomic-data-set.aspx (select "Real GDP (20IO dollars) Historical") [hereinafter USDA, International Macroeconomic Data Set] (figures based on "World Bank World Development Indicators, International Financial Statistics of the IMF, IHS Global Insight, and Oxford Economic Forecasting, as well as estimated and projected values developed by the Economic Research Service all converted to a 2010 base year"). GDP data for 2015 and, in limited cases, 2014 , are based on forecasted growth rates.

34 In the case of Germany, the dataset treats East and West Germany as if the two countries were a single country throughout the period above. For purposes of these calculations, I attributed all of the U.S.S.R.'s patents to Russia but used the GDP figures for Russia only; although this artificially increases Russia's per GDP patenting rates, this is immaterial because Russia still lags far behind the other "selected" countries for which I calculated these rates. Note that Singapore would place tenth among all countries in terms of patents per GDP but is not included because it does not fall within the category of a "selected" country. 
The patents-to-GDP measure yields rankings that are similar to the rankings derived by comparing patenting volume on a per capita basis. As in the per capita rankings, China and some large developed countries are either absent (Italy and Spain) or at the bottom of the list (the United Kingdom and France). From I980 through the late I990s, patent productivity measures for all countries except the United States (and, starting in 1993, Taiwan) clustered below 5 patents per I billion USD GDP. With the exception of the United States, Japan, Taiwan, Israel, and Korea (and, since 20I4, Finland), all other countries have remained below the threshold of 5 patents per I billion USD GDP. The United States does not significantly outperform other countries during much of this period, maintaining patent productivity measures from I 980 to 20 IO at 5 to 6 patents per I billion USD GDP. Starting in 2006 and through the present, Japan and all the patent tigers have outperformed the United States in terms of patent productivity.

These results have an important implication. As Richard Gruner has documented over a shorter time period en5 ding in 20II, U.S. patent productivity trends run contrary to widespread views that the United States has suffered from an "explosion" of patenting activity. 35 Under the per GDP measure of patent issuance, the United States experienced no significant increase in patent productivity from 1980 until 2010 . By contrast, Japan and the patent tiger countries have exhibited a significant increase in per GDP patenting activity starting in the late I990s (in the case of Taiwan, starting in the early I990s). Hence, both the per capita and per GDP measures undercut the standard view that the United States has experienced an abnormally high level of patenting activity. At least until 20IO, that proposition is only true with respect to foreign inventors.

As of 2015, the per GDP measure identifies three clusters of countries, as shown below. Within each group, countries are listed by descending order of per GDP patenting rates. In each case, $x$ denotes the ratio of patents to I billion USD GDP.

(I) Group I ( $x>$ Io): Taiwan, Korea, Israel.

(2) Group II $(5<x<$ IO): Japan, United States, Finland.

(3) Group III $(x<5)$ : Sweden, Germany, Switzerland, Canada, Denmark, the Netherlands, Austria, United Kingdom, France.

In contrast to rankings based on absolute patents or the per capita measure, the world's patent powerhouses, the United States and Japan, are not the world's leaders when evaluated on the basis of patents to GDP, although they remain closely behind. Taiwan and Israel are again members of group I, which further confirms these countries' "patent tiger" membership.

35 See Gruner, supra note 32. 
Given that Korea ranks fourth in terms of absolute patent grants and fifth in terms of per capita patent grants, and now just exceeds Israel on a patents per GDP basis, it seems appropriate to place Korea among the "patent tigers." ${ }^{6}$ Like Israel and Taiwan, Korea has become a patent powerhouse in a relatively short time since the late I990s. In 1985, Korea was granted 0.I8 patents per I billion USD GDP (the lowest among the countries set forth above); in 2015, it was granted over I4 patents on that same basis (second place, after Taiwan). Like Israel and Taiwan, it is a late-developing country; as mentioned, partially like Israel and Taiwan, it has moderately sized but not large consumer and capital markets.

\section{Patent Tigers or Patent Factories?}

Based on multiple measures, we have identified three countries that are the most intensive users of the USPTO system, outmatching to a significant extent all other countries except the United States and Japan (which they match or outmatch on some measures). We are now in a position to consider whether those measures of patenting intensity are reasonably reliable indicators of innovative performance. Economic analysis of innovation has long used patents as a proxy for innovative performance. This is in part due to convenience: patents are an easily measured output indicator and might not be any less reliable than alternative measures of innovative output. Nonetheless, patents are an inherently imperfect proxy for innovative performance. ${ }^{37}$ The concern is easily illustrated. Jurisdiction $A$ may generate more innovative output (by some non-patent measure) than jurisdiction $B$ even though it invests fewer resources into patenting. In particular, there may be a concern that jurisdiction $B$ is investing resources into strategically acquiring patents as a litigation tool, an entry-blocking device against competitors, or a bargaining chip in licensing negotiations, in which case patenting output would not primarily reflect innovative activity.

Although sensible in theory, this concern should not be overstated: when tested empirically, there is evidence that patents are a fairly reliable proxy for innovative output at the industry level, state level, and metropolitan-area level. ${ }^{38}$ Nonetheless, some legitimate concerns persist. In this part, I use multiple measures to gain insight into the productive or unproductive

\footnotetext{
36 A more broadly defined group of patent tigers would include Switzerland, Sweden, and Finland, all of which placed highly in both the per capita and per GDP rankings. Absent the Io,ooo-total-patent threshold (that is, IO,OOO patents issued from 1965 to 2015 ), Singapore would be included in that group as well.

37 See Zoltan J. Acs \& David Audtresch, Patents as a Measure of Innovative Activity, 42 KyKLOS I7I (1989); Zvi Griliches, Patent Statistics as Economic Indicators: A Survey, 28 J. Econ. Lit. I66I (I990) (providing an overview).

38 See Acs \& Audtresch, supra note 37; Zoltan J. Acs, Luc Anselin \& Attila Varga, Patents and Innovation Counts as Measures of Regional Production of Nerw Knowledge, 3I Res. POL'Y 1069 (2002).
} 
motivations behind the tiger countries' investments in acquiring USPTO patents. Each of the patent tigers scores highly on all but one measure, which tends to exclude the "patent factory" concern.

\section{A. Patent Quality}

In this part, I present data relating to two measures of patent quality: (I) "success rates," which indirectly reflect quality by measuring the percentage of a country's USPTO patent applications that mature into issued patents; and (2) citation rates, which indirectly reflect quality by measuring the number of times that a country's issued USPTO patents are cited in subsequently issued patents. Data for both measures exhibit a remarkably similar "catch-up" pattern. When the patent tigers begin using the USPTO system to any significant extent, they underperform U.S. and international comparative benchmarks on both measures. However, within a relatively short time, they typically match or exceed those benchmarks, suggesting that intensive patenting by these countries at the USPTO is reflective of underlying innovative activity.

\section{Success Rates}

The rate at which applications from residents of a particular country are granted by the USPTO, as compared with applications from residents of other countries, can provide evidence as to whether that country's patent intensity levels are reflective of underlying innovative strength. ${ }^{39}$ If a given country is patenting intensively but has a low success rate compared with other countries, that suggests that its high patenting levels are not reliably indicative of $\mathrm{R} \& \mathrm{D}$ capacities, and vice versa. For the period from 1980 to $2013,{ }^{40}$ the data discussed below indicate average annual success rates for patent applications filed by residents of each of the tiger countries, as compared with two benchmarks: (I) the average annual success rate for all non-U.S. filers; and (2) the average annual success rate for U.S. filers. With reference to both benchmarks, a similar two-stage pattern is apparent. In the early part of the period, the tiger countries perform poorly compared with both benchmarks. In the later part of the period, all tiger countries exhibit improved

39 I am aware of two prior efforts by economists to assess historical success rates among U.S. patentees: Michael McAleer \& Daniel Slottje, A Nerw Measure of Innovation: The Patent Success Ratio, 63 ScIEnTometRICS 42I (2005), and one other comparative study that assess success rates of Israeli patentees as compared with a reference group of countries from 1968 to 1997, Trajtenberg, Innovation in Israel, supra note 4. In both cases, the authors do not address the methodological challenges raised by examination lag and continuation patents. I discuss those issues below.

40 Although data exist for the period proceeding I980, the tiger countries' patenting levels were so low during this period that comparing success rates would not be a reliable indicator of patent quality. I chose the year 2013 due to the examination time lag between application and grant (or abandonment), as discussed further below. 
performance, in some cases exceeding the benchmarks. Korea outperforms both benchmarks, Taiwan approximately matches both benchmarks, and Israel intermittently approaches and moderately underperforms the benchmarks. Starting in 20IO, however, all the tiger countries approximately match both benchmarks. This pattern suggests that the tiger countries took time to learn how to achieve higher levels of patent quality, which may imply greater skill in navigating the USPTO application process, greater R\&D capacities, or a combination of both. Alternatively, the initially lower success rates might be attributable to the relatively small number of patents filed by the tiger countries during those years, which may have translated into more volatile quality across the country's patent portfolio. Although these results tend to support confidence in the quality of the tiger countries' patents, they are subject to certain methodological constraints.

\section{i. Methodological Issues}

There is an ongoing and unresolved debate over the appropriate methodology to most precisely estimate the rates at which patent applications are ultimately granted by a patent office (variously called "success rates," "grant rates," and "allowance rates," each with its own definition). The success rates shown in the graphs below are "uncorrected" because I make two simplifying assumptions. First, I calculate success rates by dividing (I) the number of patents issued to residents of that country in a given year by (2) the number of patent applications filed by a particular country's residents two years earlier. ${ }^{4 \mathrm{I}}$ The two-year period was selected based on the average historical range of lag times at the USPTO,${ }^{42}$ but it is inherently imprecise in the case of a particular application (or in the case of technology classes that tend to have longer or shorter lag times compared with the average). Second, I rely on USPTO applications data, which does not distinguish between "parent" applications and related types of "continuing" applications. A continuing application refers to several categories of patent applications that an

41 For the source of this country-specific application and grants data, respectively, see USPTO, Number of Utility Patent Applications Filed in the United States, by Country of Origin, Calendar Years I965 to Present, http://www.uspto.gov/web/offices/ac/ido/oeip/taf/appl_yr.htm (last visited Feb. 27, 20I7) [hereinafter USPTO, Number of Utility Patent Applications by Country of Origin]; USPTO, Utility Patents Report, supra note 22.

42 Subject to rounding, the two-year assumption is consistent with USPTO data on average pendency times (28.2 months from I996 to 2014). Note that the USPTO defines the pendency rate as the total time from filing of a patent application until it is abandoned or a patent issues. See USPTO, Performance \& AcCOUntability Report 4I (2OI4), https:/www.uspto.gov/sites/default/files/documents/ USPTOFY 2014 PAR.pdf. This assumption is largely consistent with the most comprehensive empirical study of time-to-grant lags (mean grant lag of 28 months and a median grant lag of 23 months) at the USPTO from 1976 to 1996. See David Popp, Ted Juhl \& Daniel K.N. Johnson, Time in Purgatory: Determinants of the Patent Lag for U.S. Patent Applications (NBER Working Paper No. 9518, 2003). Note that there is no evidence indicating significant differences in lag times as a function of the applicant's country of residence, although there are differences across certain technology classes. See $i d$. 
applicant may file at the USPTO to claim different aspects of, or improvements to, an invention disclosed in an original application or to resume prosecution of a previously filed application. Failure to distinguish between these different types of continuing applications in the USPTO data may result in imprecise estimates of the "true" success rate. ${ }^{43}$ Nonetheless, if these sources of imprecision impact all countries to an approximately equal extent, then it would still be insightful to examine the relative differences in the success rates across filers from different countries, even if the absolute values may not precisely reflect "true" success rates in the case of any specific country in any given year. ${ }^{44}$ That is the approach I follow below.

\section{ii. Benchmark I: Non-U.S. Filers}

The success rate of non-U.S. Filers (the "All-Ex-U.S." rate) provides a useful benchmark for assessing the patent quality of the tiger countries' applications. The rationale is as follows. USPTO applications filed by foreign filers should in general be of higher quality than applications filed by U.S. filers. That is because foreign filers are likely to file applications at the USPTO for higher-value applications because it requires incurring an additional cost after, as is typical, the filer has already obtained a patent in its home jurisdiction. By contrast, there is no inherent selection effect in the case of U.S. filers, which should therefore in general file applications of lower patent quality (assuming an equal distribution of $\mathrm{R} \& \mathrm{D}$ capacity and patent prosecution skills across countries). ${ }^{45}$

The graph below shows percentage deviations in the average annual uncorrected success rate for each selected country relative to the average annual uncorrected success rate for All-Ex-U.S. filers. This comparison

43 Both overestimates and underestimates can result. On the one hand, to avoid artificially decreasing the total number of applications (that is, the denominator) and thereby overestimate the success rate, it is necessary to include continuing applications that represent improvements to the invention covered by the parent application. On the other hand, to avoid artificially increasing the total number of applications and thereby underestimate the success rate, it is necessary to exclude certain types of continuing applications that solely resume prosecution of claims included in prior applications. For the most ambitious studies that address these concerns (but not on a country-specific basis), see Michael Carley, Deepak Hedge \& Alan Marco, What Is the Probability of Receiving a Patent?, I7 Yale J.L. \& Tech. 203 (2015); Ron D. Katznelson, Bad Science in Search of Bad Patents, I7 Fed. Cir. BAr J. I, 8-I6 (2007). For a study that measures allowance rates on a country-specific basis for India, Korea, and China, see Jay P. Kesan, Alan Marco \& Richard Miller, More Than Bric-A-Brac: Testing Chinese Exceptionalism in Patenting Behavior Using Comparative Empirical Analysis, 22 Mich. Telecomm. \& Tech. L. Rev. 53 (2015).

44 I note that, based on a definition of "allowance rate" as the number of issued patents in a given month divided by the number of "completed cases" (issuance of a patent or abandonment), Dennis Crouch finds trends for the period from 1986 to 2015 that are directionally similar to the trends I found using the success ratio measure described above. In particular, Crouch observes a noticeable increase in grant rates from 1998 to 200 a and then a continuous decline through 2010. See Dennis Crouch, USPTO Allowance Rate, Patently-O (Aug. IO, 2015), http://patentlyo.com/patent/2015/o8/uspto-allowance-rate. html. I observe the same pattern but the timing is about two years earlier throughout, most likely due to the fact that I measure success rate by reference to the year of the filing, not the year of issuance.

45 For a similar assumption, see William Kingston \& Kevin Scully, Patents and the Measurement of International Competitiveness 8 (Edward Elgar 2006). 
supports several observations. First, consistent with the assumption stated above, in all but two years, U.S. patent applications exhibited lower success rates compared with non-U.S. patent applications. Second, during the earlier part of the period, the tiger countries significantly underperform the All-Ex-U.S. benchmark. Third, in the later part of the period, the tiger countries show significantly improved performance. Starting in 1988, Korea approaches and then exceeds the success rate for All-Ex-U.S. filers for most years thereafter. Starting in 1992, Taiwan approximately matches the benchmark but occasionally falls below it thereafter. Starting in 1996, Israel approximately matches the benchmark but periodically falls significantly below it. ${ }^{46}$ Since 2OII, all tiger countries have exhibited comparable uncorrected success rates as compared with the benchmark. Although Israel's lower success rate compared with Korea and Taiwan should raise some concern, this has not been the case since 20II, and citation frequency data discussed below generally place the patent quality of Israeli filers above that of Korea and Taiwan. ${ }^{47}$ Additionally, the lower success rate for Israeli applications might reflect the fact that a significant percentage of Israel's patent application portfolio consists of life sciences applications, which tend to have a lower success rate as compared with other technology classes. $4^{8}$

46 In related data from an earlier period (I968 to I997), a study found that Israeli and Taiwanese applications at the USPTO had lower success rates compared with "G 7 " countries. See Trajtenberg, Innovation in Israel, supra note 4, at 12 tbl.2.

47 See Part IV.A.2.

48 See Carley, Hedge \& Marco, supra note 43, at 2I tbl.A5. 
Figure 7. Performance Relative to Uncorrected Average Annual Success Rate for USPTO Utility Patent Applications by Non-U.S. Filers (1980 to 2013)

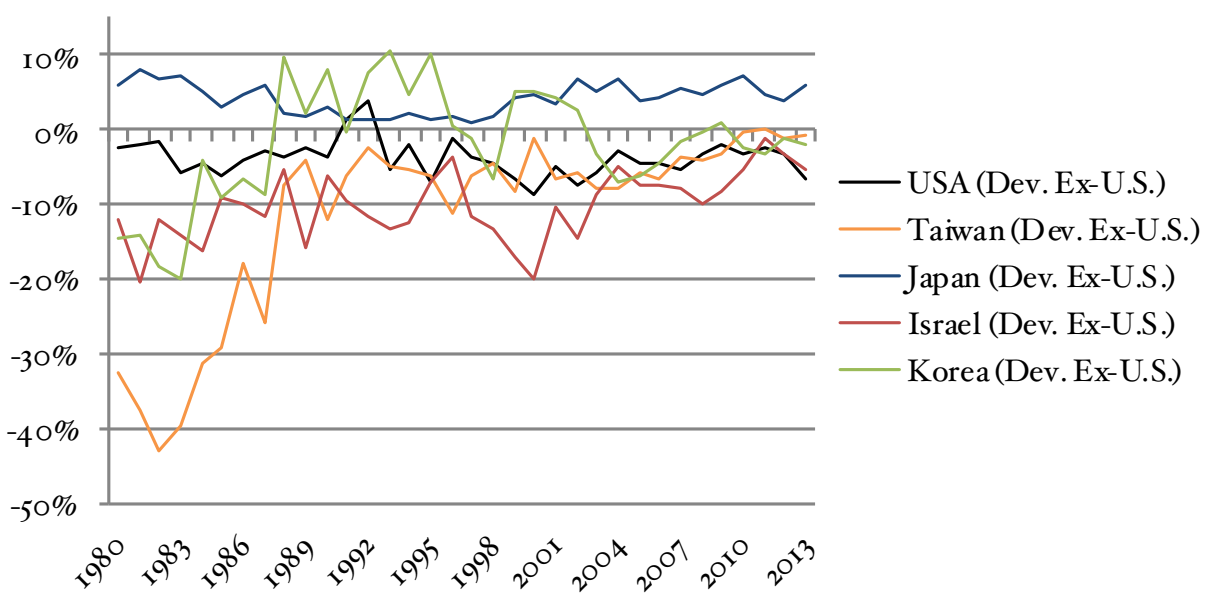

Sources: Author's calculations, based on USPTO, Number of Utility Patent Applications by Country of Origin, supra note 4I; USPTO, Utility Patents Report, supra note 22.

Note: Parenthetical abbreviation refers to "Deviation from Ex-U.S. filers' average annual uncorrected success rate."

\section{iii. Benchmark II: U.S. Filers}

Given the selection effect described above, it is useful to assess whether the tiger countries exceed U.S. success rates. The graph below shows percentage deviations in the average annual uncorrected success rate for each selected country above relative to the average annual uncorrected success rate for U.S. filers. Consistent with the selection effect, Korea has outperformed or matched the U.S. benchmark in all but one year starting in I988. Since I993, Taiwan has approximately matched or, consistent with the selection effect, slightly exceeded the U.S. rate with the exception of a single year. Israel's performance is more variable: since I988, it has periodically approached, matched, and sometimes underperformed the U.S. benchmark, although since 20 II it has matched the U.S. benchmark. Although the mixed performance of Israeli patents might raise some quality concerns, that concern does not apply after 20 II and citation frequency data discussed subsequently suggest that patents issued to Israeli filers are of especially high quality. ${ }^{49}$

49 On Israeli patents' high citation frequency, see Part IV.A.2. There is another factor that might account for the superior performance of patents issued to Korean filers, as compared with patents issued to Israeli and Taiwanese filers. The reason is that inventors resident in Israel and Taiwan often appear to use the United States as the first office in which a patent application is filed. In the case of Israel and Taiwan, existing data on filing behavior by foreign small entities from 1994 to 2003 showed that USPTO 
Figure 8. Performance Relative to Uncorrected Average Annual Success Rate for USPTO Utility Patent Applications by U.S. Filers (1980 to 2013)

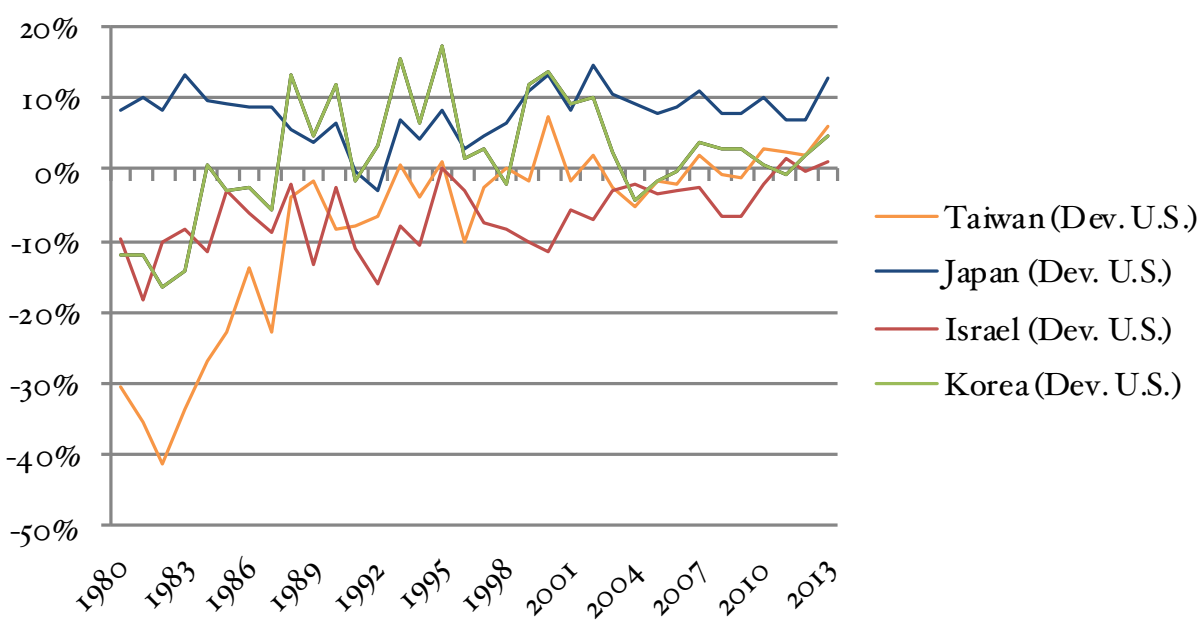

Sources: Author's calculations, based on USPTO, Number of Utility Patent Applications by Country of Origin, supra note 4I; USPTO, Utility Patents Report, supra note 22.

Note: Parenthetical abbreviation refers to "Deviation from U.S. filers' average annual uncorrected success rate."

\section{Citation Rates}

A commonly used measure to assess patent quality is citation rates. Specifically, researchers use the number of times a particular patent is cited by other patentees (so-called "forward citations") as prior art as evidence of the patent's value. Citation data support a fairly consistent catch-up pattern in the case of each of the three tiger countries, which mimics the catch-up pattern identified above using the success ratio measure. Although these countries initially lagged behind the patents of developed countries to some extent (with variation across technology sectors), it is currently the case that tiger countries' patents are typically comparable in quality to the patents of

applications constituted the filer's first application anywhere in the world about 6o percent of the time in the case of Israel and almost 92 percent of the time in the case of Taiwan. See Kingston \& Scully, supra note 45 , at I2, 95. Although these data relate solely to small entities (and cannot necessarily be generalized to all patenting activity by filers from these countries), the observed pattern is not surprising since each country's domestic market is commercially insignificant in relative terms (within the global market) and, therefore, filers may conclude that it is not worthwhile to expend filing fees on a local application. By contrast, Korea, which does have a sizable domestic market, apparently follows the more typical pattern: in the case of small entities from 1994 to 2003 , the U.S. application was the filer's first application in less than is percent of all cases. See id. 
inventors from the United States and match or exceed the quality of other large industrialized countries.

\section{i. General Citation Studies}

A study released by the U.S. Office of Technology Policy found that, from I982 to 1996 , the citation quality (as measured by a "Current Impact Index") of USPTO patents issued to Israeli and Taiwanese filers in the information technology sector approximately matched or exceeded the citation quality of USPTO patents issued to U.S. filers, although Taiwanese and Korean (but not Israeli) patents trailed U.S. patents in citation quality in the advanced materials and biopharmaceutical sectors..$^{\circ}$ The most comprehensive and updated study examined citation counts from I980 to 20II. The authors found that patentees from Israel, Taiwan, and especially Korea initially lagged significantly behind U.S. patentees in terms of citation count but had almost matched the quality of U.S. patentees by the r990s and, with a modest reversal in the case of Korea and Taiwan, continued at that level through the 2000s. ${ }^{5}$ (Note that no country in the 15 -country sample, which included Japan and other major developed countries, exceeded the U.S. citation count.) Consistent with the pattern observed in the uncorrected success rates presented above, it appears that the tiger countries acquired $\mathrm{R} \& \mathrm{D}$ (and patent prosecution) skills over time as they entered the patenting market and then matched or approached the patent quality (as measured by citation counts) of developed countries once those skills had been acquired.

\section{ii. Small-Entity Patentee Study}

A study commissioned by the World Intellectual Property Organization examined patenting behavior by foreign small entities at the USPTO from 1994 to $2003 .{ }^{52}$ In the case of Israel and Taiwan, this represents more than half of the patents issued to residents of those countries by the USPTO during this period (specifically, 56 percent of patents issued to Taiwanese filers and 52 percent of patents issued to Israeli filers). For Korea, this represented

50 See Michael B. Albert, The New Innovators: Global Patenting Trends in Five Sectors 3i fig.7 (Office of Technology Policy 2000). The "Current Impact Index" measures citation quality by comparing the citation count for a particular country's patents in a particular sector during a rolling five-year period against the expected citation count of all patents in that sector during the same period. As compared with other citation measures, the index is intended to correct for the fact that citation frequency can differ across industry sectors.

51 See Soonwoo Kwon, Jihong Lee \& Sokbae Lee, International Trends in Technological Progress: Evidence from Patent Citations, 1980-20II, I27 Econ. J. (Feature Issue) F5O (2017).

52 See Kingston \& SCully, supra note 45. Small entities were entities that filed for patents under "small entity" status, which is typically reserved for nonprofit organizations and entities that meet the Small Business Size Standards established by the Small Business Administration (SBA). Generally, the SBA definition captures entities with less than 500 employees, but firms in some industries are subject to different numerical or financial thresholds. For a summary, see $i d$. at 15 . 
only I 4.4 percent of patents issued to Korean filers during this period, ${ }^{53}$ so the results may not be indicative of the quality of patents issued to Korean filers generally. The study compared the citation frequency of patents issued by the USPTO to small entities from the United States and other countries. For these small entity patents, the tiger countries performed as follows: from 1994 to 2002 , 27.9 percent of Israeli small entity patents, 21.4 percent of Korean small entity patents, and 27.5 percent of Taiwanese small entity patents issued during that period were cited at least three times. ${ }^{54}$ Although this compares unfavorably with U.S. small firm patents (37.9 percent were cited at least three times), it compares favorably in the case of Israel and Taiwan with all other significant users of the USPTO system, including Japan (26.8 percent), Canada (30.4 percent) and Western European countries (ranging from 17 percent in the case of Spain to 27.9 percent in the case of Ireland). 55

\section{B. Innovation Inputs}

Although imperfect, data on success rates and citation frequency bolster confidence that the tiger countries' high levels of USPTO patenting activity largely reflect innovative activity, rather than strategic actions for litigation, bargaining, or other "unproductive" purposes. To gain further insight, I review evidence below on the "innovative health" of the tiger countries. Specifically, I review data relating to two key inputs into any innovation economy: (I) human capital, and (2) the R\&D investment that cultivates human capital in order to generate innovative output. On both parameters, the tiger countries perform well, matching or exceeding all other intensive users of the USPTO. Additionally, I review evidence on the technology balance of payments for each country; Israel does well on this measure, but Korea and Taiwan do not.

\section{Human Capital}

A critical element in any robust innovation ecosystem is a pool of human capital with skills suited for technological innovation and commercialization. The data support a simple conclusion: the tiger countries invest heavily in higher education and scientific research institutions and, as a result, produce a significant volume of scientific research and qualified technical personnel.

53 See id. at 15,93

54 For figures relating to Israeli and Korean patents, see $i d$. at 64 . For figures relating to Taiwan patents, see $i d$. at 98 . Note that the distribution of citation counts is highly skewed-meaning that most patents are rarely cited or are cited only once or twice. See Albert, supra note 50.

55 See Kingston \& Scully, supra note 45. 
Human capital inputs can be measured by the number of students enrolled in higher education, and specifically, fields of study relating to science and engineering. As of 2015, the OECD and Taiwan reported the following figures for the number of students who completed higher education degrees as a percentage of adults aged 25 to 64 years: (I) Israel: 49 percent; (2) Korea: 45 percent; and (3) Taiwan (25 and over, as of 20I4): 35.59 percent..$^{56}$ This compares favorably with (I) Japan (28 percent); and (2) the United States (44 percent). ${ }^{57}$ For a more up-to-date view, it may be more appropriate to focus on the population aged 30 to 34 years old. Again as of 2015, the tiger countries continue to compare favorably: (I) Israel (54 percent); (2) Korea (69 percent); (3) Japan (37 percent, for ages 25 to 34 years old); and (4) the United States (47 percent). ${ }^{5}$ If we examine data (as of 2002 and 20I2, respectively) on the percentage of students entering higher education institutions in engineering and science-related fields, the tiger countries excel, as compared with the United States: (I) Korea (39 percent and 32 percent) (the highest in the world); (2) Japan (26 percent and 23 percent); (3) Israel (22 percent and I9 percent); and (4) the United States (I6 percent and I6 percent). ${ }^{59}$ The tiger countries compare favorably if we examine data (as of 20I2) on the percentage of GDP invested in educational institutions: (I) Korea (6.7 percent); (2) Israel (6.5 percent); (3) the United States (6.4 percent); and (4) Japan (5 percent). ${ }^{60}$

These large educational investments yield large numbers of $\mathrm{R} \& \mathrm{D}$ personnel and scientific publications when measured on a per capita basis. In 20I2, the OECD reported the following figures for the number of fulltime researchers per thousand employment: (I) Israel: 17.4 (the highest in the world); (2) Korea: I2.8; (3) the United States: 8.7; (4) Japan: IO; and (5) Taiwan: I2.9. ${ }^{6}$ Additionally, based on a ranking of countries by the annual volume of articles in the "top quartile" of scientific journals, the tiger countries excel: as of 2013 , Israel had more publications per million USD GDP than the United States, Taiwan and Korea had slightly less, and all three patent tigers exceeded Japan. ${ }^{62}$ Based on a ranking of citations per scientific article from

\footnotetext{
56 OECD, Education at a Glance 2015 (2015); Statistical Yearbook of the Republic of China 2014 (Chinese Statistical Agency 2015), http://ebook.dgbas.gov.tw/public/Data/5121585452KIDMH9KP. pdf.

57 Id. The data for Japan exclude “short cycle” tertiary education, which might account for Japan's surprisingly low rates on this measure.

58 Id. Information for Taiwan is not available.

59 OECD, Science, Technology and Industry Scorecard 20i5: Innovation for Growth and SOCIETY ch. 2 (2015). Information for Taiwan is not available.

60 OECD, Education at a Glance 2015, supra note 56, at 233 tbl.B2.I. Information for Taiwan is not available.

61 20i5/2 OECD, Main Science and Technology Indicators (2016). Researchers are defined as "professionals engaged in the conception or creation of new knowledge, products, processes, methods and systems, as well as the management of the projects concerned." In the case of Israel, the employment figures exclude all or most defense-related $R \& D$ positions.

62 OECD, Science, Technology and Industry Outlook 20I4 (2014). Specifically, Israel had 0.04 publications per million USD GDP (eighth in the world), the United States had 0.03 publications
} 
1996 to 20I4, Israel ranks highly (tenth in the world), although Korea and Taiwan do not (twenty-ninth and thirtieth in the world, respectively). ${ }^{63}$

\section{R\&D Intensity}

Clearly a necessary input in any innovation economy is a high level of $R \& D$ investment, typically measured by R\&D intensity (defined as R\&D expenditures as a percentage of GDP) to permit comparison across jurisdictions of varying size. The graph below displays rankings for the tiger countries, along with the United States and Japan, from 1995 to 2015. The tiger countries score favorably compared with the United States and Japan. Based on R\&D expenditures per GDP, Israel leads all five countries from 1999 to 2015 (except in 20I4, when it was slightly overtaken by Korea). During much of that period, Taiwan approaches the United States' R\&D intensity levels and then exceeds it starting in 2009. Clearly, the tiger countries' high and increasing levels of USPTO activity are accompanied by high and increasing levels of $\mathrm{R} \& \mathrm{D}$ intensity.

Figure 9. National R\&D Expenditures as Percentage of GDP (1995 to 2015)

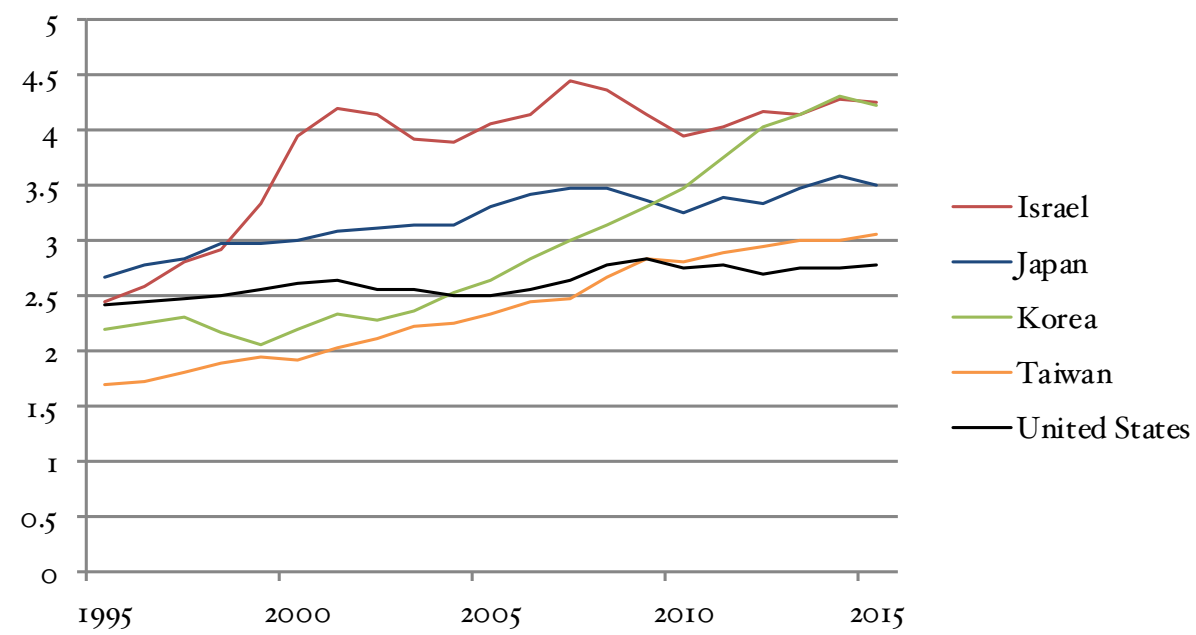

Source: OECD, Gross Domestic Spending on R\&D, https://data.oecd.org/rd/gross-domesticspending-on-r-d.htm\#indicator-chart (last visited Feb. 28, 2017).

(twenty-first in the world), Taiwan had 0.02 publications (twenty-second in the world) and Korea had 0.02 publications (twenty-seventh in the world).

63 See Guillermo Lemarchand, Eran Leck \& April Tash, Mapping Research and Innovation in the State of Israel iio (UNESCO 2016). 


\section{Technology Balance of Payments}

The technology balance of payments refers to the difference between (I) payments made by firms in country $X$ to use or acquire IP rights held by firms located outside that country, and (2) payments received by firms in country $X$ to use or acquire their IP rights from firms located outside that country. ${ }^{64}$ Where outgoing payments exceed incoming payments, an IP trade deficit results; in the converse case, the country enjoys an IP trade surplus. For 20I4 (the last year for which the OECD makes available data for all five countries under discussion), Israel, like the United States and Japan, enjoyed a significant IP trade surplus (\$9.96 billion, representing 3.47 percent of Israel's nominal 2014 GDP) ${ }^{65}$ This further confirms the view that Israel's intensive patenting at the USPTO reflects underlying innovative strength. For the same year, however, both Korea and Taiwan showed IP trade deficits: $\$ 5.78$ billion in the case of Korea (representing 0.34 percent of nominal 2014 GDP) and $\$ 4.26$ billion in the case of Taiwan (representing 0.39 percent of nominal 2014 GDP). ${ }^{66}$ This should raise some concern as to the extent to which Korea's and Taiwan's high levels of patenting intensity fully reflect underlying innovative strength. However, it should be noted that these countries' IP trade deficits might reflect the fact that, unlike Israel, these countries maintain significant hardware manufacturing operations located at the intermediate point of the global technology supply chain and therefore rely on technology inputs sourced from upstream R\&D suppliers. I will return to this point below in the case study of Taiwan.

\section{How Patents Support Global Supply Chains}

We have now established three important points: (I) over approximately the past three decades, there has been a significant increase in foreign use of the USPTO, in particular by East Asian countries and Israel, which are substantially responsible for the first "explosion" in patent issuance at the USPTO in the I990s; (2) the tiger countries (and Japan) are currently the most intensive foreign users of the USPTO as measured by patents issued per capita or per GDP (or, in some cases, absolute numbers of patents issued); and (3) subject to limited qualifications, the tiger countries' intensive levels of patent

${ }^{64}$ For a fuller definition, see OECD, Main SCience and Technology Indicators, supra note 6I, \$I.I. "IP rights" are understood to include "patents, licenses, trademarks, designs, inventions, know-how and closely related technical services." Id.

65 Author's calculations, based on technology payments and technology receipts reported in OECD, Main Science and Technology Indicators, http://stats.oecd.org/Index.aspx?DataSetCode=MSTI_PUB (last visited Feb. 28, 2017). For the GDP figures, see International Monetary Fund [IMF], World Economic Outlook Database (Apr. 2015), https://www.imf.org/external/pubs/ft/weo/2015/or/weodata/ WEOAproor 5 all.xls.

${ }_{66}$ See supra note 65 and accompanying text. 
acquisition appear to reflect underlying (and growing) strengths in innovative capacity and performance. In this part, I propose an economic rationale behind the tiger countries' intensive patenting strategies. Specifically, I argue that U.S. patents have enabled the tiger countries-and, more generally, any country with strong innovation capacities but limited internal access to commercialization inputs and limited domestic consumer markets (or some combination thereof)-to overcome the transactional hazards involved in accessing the commercialization inputs and consumers located in foreign markets.

\section{A. Transactional Hazards in Innovation Economies}

Following Michael Porter's canonical contribution on comparative national advantage, we can situate national economies at three possible stages of development: factor; efficiency; and innovation. ${ }^{67}$ Factor economies compete on the basis of abundant natural resources and low-cost labor; efficiency economies compete on the basis of process efficiencies that counteract depleting natural resources and rising labor costs; innovation economies compete on the basis of innovation by developing new products, processes, or both. In Porter's theory, successful economies convert "selective disadvantages" into "selective advantages." That is, an economy implicitly pursues competitive advantage at a particular stage of development, based on the economy's factor disadvantage. ${ }^{68}$ To use one of Porter's examples: Dutch entrepreneurs addressed year-round domestic demand for fresh flowers by developing greenhouse methods for growing plants indoors, thereby overcoming a selective natural-resource disadvantage due to Holland's winter climate. Subsequently, the industry extended its newly acquired selective advantage through innovations in long-distance transport and refrigeration, which enabled it to dominate foreign markets for the same product. ${ }^{69}$

In technology-intensive markets, Porter's theory requires modification because it does not address the transactional hazards encountered by an economy that seeks to move into the innovation stage. Specifically, it does not address the transactional hazards inherent in exchanges involving informational assets that move between entities located at different levels of a technology supply chain. As the literature on technology transfer has observed, any upstream-downstream interaction in a disaggregated supply chain may involve the transmission of informational assets, which could then be used by the recipient firm to the competitive disadvantage of the firm that conveyed

67 See Michael E. Porter, The Competitive Advantage of Nations 546-56 (Free Press i99o).

68 See id. at $8 \mathrm{I}-85$.

69 See id. at 85 . 
that asset..$^{\circ}$ Those hazards are compounded in the case of a firm located in a smaller economy that can only extract the full value of its $R \& D$ investment by delivering goods incorporating innovation inputs to larger foreign target markets, which raises logistical and transactional complications. Doing so requires either capital-intensive forward vertical integration or contractual interactions with third parties that are the most efficient sources of the capital, infrastructure, and expertise required to penetrate target foreign consumption markets. If the former option is not feasible due to capital and expertise constraints, then the latter represents the only feasible pathway to market.

It is precisely at this point that patents (and, specifically, patents issued by the target consumption market) can play a critical role in enabling an economy-and especially a smaller economy-to move toward the innovation stage. Suppose a firm located in a small foreign economy has developed a new technology and wants to maximize returns on its investment by selling its technology, or products and services incorporating its technology, in the U.S. market. To do so, the firm must successfully execute a host of commercialization tasks, such as testing and regulatory approval, production, distribution, marketing, and post-purchase support. With respect to each commercialization task, the firm can choose to execute that task either "in house"-makeor "on the market"-buy. Applying the logic of Ronald Coase, if we assume away transaction costs, the firm's make-or-buy choice with respect to each commercialization task would simply reflect a cost comparison between internal and external entities that could execute that task (assuming comparable quality levels)..$^{7 \mathrm{I}}$ As Coase emphasized, however, moving functions out of the firm and into the market typically involves transaction costs that might render doing so uneconomical. Generically, those transaction costs involve search, negotiation, drafting, monitoring, and enforcement costs inherent in arm's-length contractual relationships. In the case of transactions involving informational assets, a firm often faces additional costs associated with protecting those assets against expropriation, both during the commercialization stage leading to market release and in the distribution stage after market release.

Specifically, firms and other entities in technology markets face three categories of transactional hazards in delivering an innovation from the "lab"

70 See Timothy J. Sturgeon \& Ji-Ren Lee, Industry Co-Evolution: A Comparison of Taiwan and North American Electronics Contract Manufacturers, in Global Taiwan: Building Competitive Strategies in a New International Economy 33, 42-43 (Suzanne Berger \& Richard K. Lester eds., Routledge 2015) [hereinafter Global Taiwan]; John M. De Figueredo \& David J. Teece, Mitigating Procurement Hazards in the Context of Innovation, 5 Indus. \& Corp. Change 537, 548-49 (1996); David J. Teece, The Market for Know-How and the Efficient International Transfer of Technology, 458 Annals Acad. Pol. \& Soc. SCi. 8I, $85-86$ (I98I).

71 See Ronald H. Coase, The Nature of the Firm, 4 EсоNomica 386 (1937). 
to the target consumption market. Each type of hazard arises as a function of the transactional structure selected by a firm to reach market. Figure ro depicts the transactional paths followed by three paradigm firms $A, B$, and $C$. Whatever the transactional path selected, the firm must execute three categories of supply-chain functions: (I) innovation; (2) production; and (3) distribution. Each firm can elect to execute each of these functions internally (make) or externally (buy). The combination of make or buy decisions determines the transactional path to market. If a firm selects the buy option with respect to any particular function, it must anticipate how to agree upon the terms of access with outside suppliers and then monitor and enforce compliance with those terms.

Figure Io. Alternative Supply Chains in Technology Markets

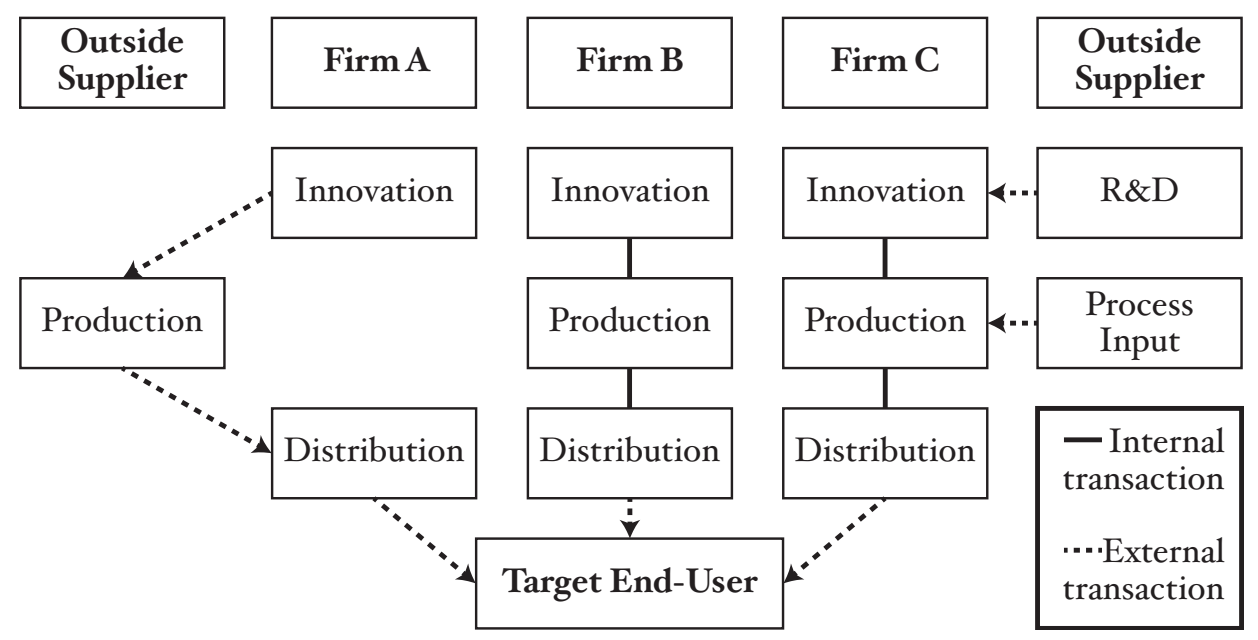

Based on these stylized supply chain configurations, we can identify three paradigm types of transactional hazards that may raise obstacles in embodying an innovation in a consumption good for delivery to the target end-user market.

\section{Outsourcing Hazards}

Firm $A$ has developed an innovation and now must set up a production and distribution infrastructure to monetize it. Suppose the firm can execute the production function most efficiently by contracting with outside suppliers for that purpose. Or suppose (not shown graphically above) that the firm's technology is a component designed to be incorporated into an existing technology or some other existing, larger, and more complex product. In either case, the upstream $\mathrm{R} \& \mathrm{D}$ firm must protect against the expropriation risk 
posed by its potential downstream partners, who will require access to the firm's knowledge assets during the negotiation and implementation process.

\section{Insourcing Hazards}

Firm $C$ has developed an innovation and now seeks to monetize it through production and distribution. Unlike firm $A$, it wishes to undertake these functions internally but, like firm $A$, it lacks the expertise to do so. Therefore, firm $C$ must contract with outside suppliers of the process inputs required to complete those functions. Alternatively, suppose that firm $C$ has independent production and distribution capacities but requires a complementary technology input to complete the innovation function. In that case, firm $C$ must contract with outside suppliers of the required $\mathrm{R} \& \mathrm{D}$ input. To obtain these inputs, firm $C$ must credibly commit not to expropriate suppliers' process or $\mathrm{R} \& \mathrm{D}$ inputs except upon agreed terms of use.

\section{Distribution Hazards.}

Firm $B$ has developed an innovation, executed production, and is now ready to distribute it into the target market. Even though it has executed all functions in-house, firm $B$ still faces an expropriation hazard: namely, it must protect its technology against expropriation by imitative competitors following release of its product into the target consumption market. Assuming low reverse-engineering costs, those competitors will have an inherent advantage because they have presumably not borne much of the firm's product development and commercialization costs.

\section{Summation}

Understanding the menu of informational hazards faced by firms in technology markets-and, in particular, disaggregated technology markets-provides the basis for appreciating the role of patents in enabling those supply chains to operate efficiently. Specifically, reliably enforceable patents combined with contractual agreements can mitigate transactional hazards by limiting expropriation opportunities and thereby enabling parties to regulate the flow of informational assets among transacting parties. In the case of outsourcing hazards, patents regulate information flow between, on the one hand, an innovator-firm and, on the other hand, the supplier of a production or distribution input required to complete the commercialization process. Without patents, it is difficult for the outside supplier to credibly commit against expropriating information disclosed to it. Although reputational forces might constrain supplier opportunism in certain settings, it is not a fail-safe deterrent, especially in transactions involving non-repeat-play counterparties, 
technologically sophisticated counterparties, or large commercial stakes. ${ }^{72}$ In the case of insourcing hazards, a patent provides the legal foundation behind a licensing transaction that regulates information flow between, on the one hand, the innovator-firm and, on the other hand, the holder of the product or process technology input required to complete commercialization. The same informational hazard persists but operates in the opposite direction: that is, without patents, it is difficult for the innovator-firm to credibly commit against expropriating the informational assets provided to it beyond the agreed-upon terms of use. Finally, in the case of distribution hazards, patents perform their conventional function by impeding reverse engineering in the target consumption market and providing the innovator-firm (or a commercialization entity that holds an interest in the innovation asset) with a time window in which it can earn a return on the research and commercialization efforts behind the new product.

\section{B. Patents and Specialization in Global Technology Supply Chains}

If patents mitigate transactional hazards that would otherwise frustrate exchanges between the suppliers of innovation and non-innovation inputs in the commercialization process, it follows more generally that patents might facilitate parties' ability to craft and adjust supply-chain structures so as to execute the innovation and commercialization process as efficiently as possible. In particular, scholars have argued that patents sometimes enable innovation to take place in specialized $R \& D$ entities that contract with financing, production, and distribution partners to execute the commercialization process. ${ }^{73}$

Three bodies of evidence support this proposition most directly. First, extensive studies of late nineteenth-century technology markets in the United States found that the availability of secure patent rights facilitated the formation of small R\&D-intensive entities, which then contracted with external sources to secure the funding required to commercialize those entities' innovations. ${ }^{74}$ Relatedly, recent empirical research has shown that patent-based commercial exchange during the nineteenth and early twentieth centuries operated internationally, enabling the diffusion of knowledge

\footnotetext{
72 For fuller analysis of this point, see Jonathan M. Barnett, Three Quasi-Fallacies in the Conventional Understanding of Intellectual Property, I2 J.L. ECON. \& POL'Y I, IO-I2 (2OI6).

73 See supra note 3.

74 See Naomi R. Lamoreaux \& Kenneth L. Sokoloff, Inventors, Firms, and the Market for Technology in the Late Nineteenth and Early Trentieth Centuries, in Learning by Doing In Markets, Firms, and Countries I9 (Naomi R. Lamoreaux, Daniel M.G. Raff \& Peter Termin eds., Univ. of Chicago Press 1999); Naomi Lamoreaux \& Kenneth L. Sokoloff, The Market for Technology and the Organization of Invention in U.S. History, in Entrepreneurship, Innovation and the Growth Mechanism of the Free-Enterprise Economies 213 (Eytan Sheshinski, Robert J. Strom \& William J. Baumol eds., Princeton Univ. Press 2007); Kenneth L. Sokoloff \& B. Zorina Khan, The Democratization of Invention During Early Industrialization: Evidence from the United States, 1790-I846, 50 J. Econ. Hist. 363 (1990).
} 
across countries..$^{75}$ Second, scholars have repeatedly found that transactional structures are sensitive to differences in the strength of patent protection across countries. In countries with strong patent rights, firms tend to structure their foreign direct investments through a contractual relationship with a local partner, rather than through a directly owned subsidiary. The effect is reversed in countries with weak patent rights. ${ }^{76}$ Consistent with the proposition above, it appears that expropriation risk precludes or counsels against undertaking commercialization on the open market, compelling firms to select make even if buy would be the lower-cost option in a zero transaction-cost environment. Third, studies of the biotechnology industry have established that upstream R\&D suppliers-typically, scientist-founded startups-are especially dependent on patents, which are then used to enter into transactions with larger pharmaceutical companies that have comparative advantages in financing and executing the testing, production, and distribution functions required to reach market. ${ }^{77}$

Existing theoretical discussions and related empirical evidence support the view that patents expand markets' ability to design structures for allocating innovation and commercialization functions to the set of least-cost providers, at the levels of both transactional design and organizational design. That is: patents are an enabling mechanism behind the division of labor, and associated efficiencies, that underlie the technology-intensive segments of a well-functioning market economy. This logic can be extended a step higher to the level of a national economy. If patents enable markets to construct disaggregated transactional and organizational structures for executing innovation and commercialization functions (a transaction-level effect), which in turn enables the viability of stand-alone $\mathrm{R} \& \mathrm{D}$ suppliers (a firm-level effect), then patents may facilitate the specialization by entire countries (or large portions of the economies of those countries) in the development and supply of particular inputs in a technology supply chain (an economy-level effect). From a

75 See B. Zorina Khan, Selling Ideas: An International Perspective on Patenting and Markets for Technological Innovations, 1790-1930, 87 Bus. Hist. Rev. 39 (2013).

76 See Joanne E. Oxley, Institutional Environment and the Mechanisms of Governance: The Impact of Intellectual Property Protection on the Structure of Inter-Firm Alliances, 38 J. ECON. BeHAV. 283 (I999); Bharat Anand \& Tarun Khanna, The Structure of Licensing Contracts, 48 J. Indus. Econ. IO3 (2000). Other studies similarly find that weak-patent jurisdictions attract firms that confine knowledge production and exchange within the firm. See, e.g., Minyuan Zhao, Conducting R\&D in Countries with Weak Intellectual Property Rights Protection, 56 Mgmt. SCI. II85 (2006). Similarly, another study finds that firms tend to export to, or manufacture (but decline to conduct R\&D) in, jurisdictions with weak IP rights. See Beata K. Smarzynska, Composition of Foreign Direct Investment and Protection of Intellectual Property Rights: Evidence from Transition Economies (World Bank Policy Research Department, Working Paper No. 2768, 2002).

77 See Toby E. Stuart, Salih Zeki Ozdemir \& Waverly W. Ding, Vertical Alliance Networks: The Case of University-Biotechnology-Pharmaceutical Alliance Chains, 36 Res. Pol'y 477 (2007); Josh Lerner \& Robert P. Merges, The Control of Strategic Alliances: An Empirical Analysis of Biotechnology Collaboration (National Bureau of Economic Research, Working Paper No. 6014, 1997); Gary P. Pisano, The Governance of Innovation: Vertical Integration and Collaborative Agreements in the Biotechnology Industry, 20 Res. Pol'y 237 (I991). 
development perspective, this is a potentially critical achievement: reducing the transaction costs of information exchange facilitates an emerging economy's ability to enter the global technology market without having to incur the enormous costs, and acquire the complex knowledge base, required to construct and operate a fully integrated and stand-alone international supply chain to reach target consumption markets..$^{78}$

In particular, patents may enable two paradigm types of specialized innovation economies that can make surgical entries at discrete points on a global technology supply chain. First, patents might enable upstream innovation economies that specialize in the development of product technologies that operate as $\mathrm{R} \& \mathrm{D}$ inputs for the development, production, and distribution stages located downstream on the technology supply chain. As I will discuss in the following part, this largely describes the Israeli innovation economy. Second, patents may enable "midstream" innovation economies that specialize in process technologies that incorporate $\mathrm{R} \& \mathrm{D}$ inputs into larger technology bundles for consumption by intermediate or end-users in foreign target consumption markets. As I will discuss in the following part, this describes in substantial part the Taiwanese innovation economy. In other cases, patents may enable mixed-type economies populated by entities that operate in multiple segments of a technology supply chain. This appears to be the case in the Korean innovation economy, in which large vertically integrated firms (especially the Samsung, LG, Hynix, Daewoo, and Hyundai corporate groups) are the country's most prominent users of the USPTO system. Note, however, that even these integrated firms sometimes supply "mid-stream" commercialization inputs (in Samsung's case, it provides chip fabrication services to firms such as Apple ${ }^{79}$ ), whereas research entities such as Korea's Electronics and Telecommunications Research Institute (one of Korea's leading USPTO users) act solely as upstream suppliers of R\&D inputs. ${ }^{8 \circ}$ In the case of electronics manufacturers in Korea and Taiwan, USPTO patents might

78 The economics of development literature has observed how improvements in communications and transportation technology has enabled emerging markets to avoid the costs involved in establishing a self-contained supply-chain infrastructure. See, e.g., Richard Baldwin, Global Supply Chains: Why They Emerged, Why They Matter, and Where They Are Going, in Fung Global Institute, Nanyang Technological University \& World Trade Organization, Global Value Chains in a Changing World I3, 24 (Deborah K. Elms \& Patrick Low eds., WTO Publications 2013). I extend this point by showing that intellectual property rights play a role in mediating the expropriation risks that would otherwise raise an obstacle to that development strategy. For an earlier historical period covering the nineteenth and early twentieth centuries, Zorina Khan has presented evidence showing how patents facilitated the international diffusion of technological knowledge through assignment and sale transactions (in significant part, to further the business strategies of large U.S. and German companies). See Khan, supra note 75.

79 See Quinten Plummer, Apple Taps Samsung to Make A9 Chips for Next Generation iPhones and Other Devices, TeCH Times (Apr. 6, 2015), http://www.techtimes.com/articles/44308/20150406/apple-taps-samsung-to-make-a9-chips-for-next-generation-iphones-and-other-idevices.htm.

80 It should be noted that, based on USPTO data, these large integrated firms represent less than Io percent of total USPTO patents issued to Korean inventors from 2000 to 2015 . Hence, further study might reveal significant patenting activity by smaller and medium-sized entities in the Korean economy. 
additionally assist in deterring litigation or negotiating favorable licensing terms from holders of required technology inputs (which corresponds to the "insourcing" scenario described previously). ${ }^{81}$

\section{Case Studies: Israel and Taiwan}

The following case studies of Israel and Taiwan represent a preliminary effort to apply the theoretical framework proposed above to two specific innovation economies. ${ }^{82}$ I rely on USPTO data to identify each economy's leading users of the USPTO system, other data to identify those firms' position in the technology supply chain, and existing historical and empirical research on these countries' technology markets to assess the extent to which USPTO patents enable firms in these countries to access the pipeline required to embed innovation inputs into viable consumption goods for the U.S. market. Despite important differences in each country's primary point of specialization on the global technology supply chain, a common narrative emerges from each case study. In a relatively short period of time, each country has accelerated its movement up the development ladder to become one of the world's exceptional innovation economies. Following Porter's framework, these economies were burdened with a dual selective disadvantage in the form of meager natural resources and small domestic consumer markets. In response, both economies cultivated selective advantages in the form of the technological capacities required to build and maintain an innovation economy. Although further inquiry is warranted in each case,${ }^{83}$ USPTO patents appear to have provided an important tool for each economy to capture returns on these human and intellectual capital investments through relationships with third-party holders of complementary innovation and non-innovation inputs.

\section{A. Case Study I: Israel}

Although Israel's leadership in the world technology market has received significant attention in the business press, it has received little dedicated attention in the scholarly literature. ${ }^{84}$ Despite having land territory approx-

81 I thank Colleen Chien for this observation. For further discussion, see Part IV.B.2.

82 Korea is omitted due to space constraints.

83 In particular, a more complete discussion of the role of USPTO patents in each country's innovation environment would provide closer analysis of firms other than the top 15 assignees in each country's USPTO patentee population (the focus in the discussion below) and analysis of the interaction between the USPTO system and each country's local patent system.

84 For some exceptions, see Shiri M. Breznitz, Cluster Sustainability: The Israeli Life Sciences Industry, 27 Econ. Dev. Q. 29 (2013); Jerome S. Engel \& Itxaso del-Palacio, Global Clusters of Innovation: The Case of Israel and Silicon Valley, 53 CAL. MGMt. Rev. 27 (2011); Gil Avnimelech \& Morris Teubal, Creating Venture Capital Industries That Co-Evolve with High Tech: Insights from an Extended Industry Life Cycle Perspective of the Israeli Experience, 35 Res. Pol'y 1477 (2006); Erran Carmel \& Catherine de Fontenay, Israel's Silicon Aadi: The Forces Behind Cluster Formation, in Building High-Tech Clusters: Silicon Valley and Beyond 40 
imately equal to, and population slightly smaller than, New Jersey, it was the fourth-largest national recipient of venture capital funding outside of the United States from 2006 to $20133,{ }^{85}$ as of 2014 had more firms listed on Nasdaq than any country other than the United States and China, ${ }^{86}$ and, as of 2015, was the second-largest national recipient of USPTO patents on a per capita basis. ${ }^{87}$ Technological leadership has been accompanied by economic growth: in 1980 , it had a per capita GDP of $\$ 6,018$, as compared with $\$ 8,355$ for Italy; in 2014 , it had a per capita GDP of $\$ 36,990$, as compared with $\$ 35,823$ for Italy ${ }^{88}$ Unsurprisingly, Israel's rise to innovation leadership has coincided with an increase in $R \& D$ investment: Israel's business $R \& D$ (excluding defense-related R\&D) increased from 2.8 percent of GDP during the 1980 s to 4.8 percent of GDP during the $1990 \mathrm{~s}^{89}$ and, since 1999 , its total $\mathrm{R} \& \mathrm{D}$ intensity has been the highest in the world. ${ }^{\circ}$ Given the absence of a large domestic market and the presence of high labor costs (two selective disadvantages in Porter's terminology), the country's technology firms must rely on foreign markets to extract a return from $\mathrm{R} \& \mathrm{D}$ investments.

\section{Background}

Israel's innovation economy has been promoted by three primary forms of government intervention. First, the government's heavy investment in defense (representing 5.9 percent of GDP in 2014, as compared with 3.5 percent for the United States and I percent for Japan) ${ }^{91}$ has spawned spillover effects in the civilian market. ${ }^{92}$ Second, the Office of the Chief Scientist provides grants for technology startups. ${ }^{93}$ Third, the Israeli government

(Timothy F. Bresnahan \& Alfonso Gambardella eds., Cambridge Univ. Press 2004); Manuel Trajtenberg, Government Support for Commercial R\&D: Lessons from the Israeli Experience, 2 InNOvation Pol'y \& ECON. 79, 88-89 (2002); Trajtenberg, R\&D Policy in Israel, supra note 4; Trajtenberg, Innovation in Israel, supra note 4.

85 Peter Vanham, Which Countries Have the Most Venture Capital Investments?, World ECON. F. (July 28, 2015), https://www.weforum.org/agenda/2015/o7/which-countries-have-the-most-venture-capital-investments/ (citing Ernst \& Young, Venture Capital Insights-4Qi4 (2OI5)). For this purpose, the report treats the European Union as a single country.

86 See Ari Rabinovitch, Nasdaq Expects Increase in IPOs from Israeli Firms, Reuters (May II, 2OI4), http:// www.reuters.com/article/us-nasdaq-israel/nasdaq-expects-increase-in-ipos-from-israeli-firms-idUSBREA4A04320I405II.

87 See supra Figure 6.

88 IMF, World Economic Outlook Database, supra note 65. Figures are expressed in current prices.

89 See Daphne Getz \& Vered Segal, The Israeli Innovation System: An Overview of National Policy and Cultural Aspects, Samuel Neaman Institute, Technion-Israel Institute of TechNology 7 (2008)

90 See supra Figure 9.

91 World Bank, Military Expenditure (\% of GDP), http://data.worldbank.org/indicator/MS.MIL. XPND.GD.ZS.

92 See Orna Berry \& Daniel Wasserteil, Israel: The Technology Industry as an Economic Growth Engine Creating a Nationwide Cluster of Innovation, in Global Clusters of Innovation: Entrepreneurial Engines of Economic Growth Around the World i87, I9o (Jerome S. Engel ed., Edward Elgar 20I4) [hereinafter Global Clusters of Innovation]; Getz \& Segal, supra note 89, at 7.

93 For detailed description of these programs, see Daphne Getz, Dan Peled, Tsipy Buchnik, Ilia Zatcovetsky, Eran Leck \& Ella Barzani, Science, Technology and Innovation Indicators in 
established in the early I990s the Yozma program, in which the government acted as a quasi-venture capitalist in the local technology industry. This successfully triggered a robust venture-capital market. From 2005 to $201 \mathrm{I}$, Israel received the fourth-largest share of total venture capital investment worldwide, after the United States, Europe, and China, representing more than 8 percent of all venture capital investments in the top six country-level recipients of venture capital investment. ${ }^{94}$

\section{Patent Data: Firm and Market Characteristics}

In this part, I provide more detailed information on the types of entities in Israel that invest most actively in filing for USPTO patents and discuss potential rationales behind those efforts.

\section{i. Patent Assignee Population}

When a patent is issued by the USPTO, it will state, if applicable, the firstnamed assignee of the patent. When this appears, it is typically the inventor's employer, with whom the inventor has entered into a pre-assignment contract. Data on the first-named assignees of patents issued to Israeli inventors provide a window into the primary types of entities that undertake $\mathrm{R} \& \mathrm{D}$ (or, at least, patentable $\mathrm{R} \& \mathrm{D}$ ) in the Israeli economy. ${ }^{95}$ For this purpose, I examined a pool consisting of first-named assignees identified by the USPTO in its country-based breakdown of utility patent grants (which includes all such assignees other than entities that were first-assigned fewer than five USPTO patents from 1969 to 2015). ${ }^{6}$ This "identified first-named assignees" pool represents a significant majority (73 percent) of USPTO patents issued to Israeli filers from 2000 to $2015 .{ }^{97}$ If we consolidate parents

\footnotetext{
Israel: An International Comparison 43-45 (Samuel Neaman Institute 4th ed. 2013); Avnimelech \& Teubal, supra note 84; Trajtenberg, Government Support, supra note 84, at 88-89.

94 Author's calculations, based on data in Ernst \& Young, Globalizing Venture Capital: Global Venture Capital Insights and Trends Report io (2OII). The top 6 countries (as of 2OII) are the United States, Europe, China, Israel, India, and Canada.

95 Note that this pool does not prominently reflect certain Internet and software companies that do not rely heavily on patent protection-areas in which Israel has recognized innovative capacities.

96 USPTO, Extended Year Set, Utility Patent Report, Patenting by Geographic Origin (State and Country) - Breakout by Organization, https:/www.uspto.gov/web/offices/ac/ido/oeip/taf/stcasga/regions_ stcorg.htm (last visited Aug. 28, 20I6) [hereinafter USPTO, Patenting by Geographic Origin-Breakout by Organization]. This five-patent limitation appears to be the reason why the pool of patents for which the USPTO identifies first-named assignees (as well as individually owned patents that do not name any such assignee) is smaller than the total pool of patents issued to Israeli filers during this period as reported elsewhere by the USPTO. See USPTO, Utility Patents Report, supra note 22.

97 Author's calculations, based on USPTO, Patenting by Geographic Origin-Breakout by Organization, supra note 96 (providing information on first-named assignees, with country breakdown); USPTO, Utility Patents Report, supra note 22 (providing information on total utility patents, with country breakdown).
} 
and subsidiaries within this assignee pool,,$^{98}$ there are 648 unique identified first-named assignees of patents issued to Israeli filers during this period. From the perspective of entity type, the assignee population falls into three major categories: (I) academic research institutions; (2) local subsidiaries of large multinational firms; and (3) local technology firms. As discussed further below, local subsidiaries of foreign multinationals often started as local firms that were acquired by the multinational. From the perspective of industry type, the assignee population falls mostly into three categories: (I) information and communications technology (ICT) (defined broadly to include software, hardware, and telecommunications); (2) life sciences (defined broadly to include biopharmaceuticals and medical devices); and (3) defense or military systems. This industry type distribution tracks other data on the patent classes favored by Israeli USPTO filers. (From 2000 to 2015 , Israeli filers patented most heavily in patent classes relating to pharmaceuticals, surgical devices, digital communications, image analysis, and data transfer. ${ }^{99}$ )

The charts below show, respectively, from 2000 to 2015: (I) the percentage that each entity type represents out of the total pool of identified first-named assignees of USPTO patents issued to Israeli filers; and (2) the percentage that each industry type represents out of that same pool.

98 Consolidation of parents and subsidiaries was based on commonality of names, supplemented by information in companies' annual reports, company websites, and the Hoover's company database. In cases not involving commonality of names, additional parent-subsidiary relationships were identified through data collected on acquisitions of Israeli firms by foreign multinationals. For patent data, see USPTO, Patenting by Geographic Origin-Breakout by Organization, supra note 96. For this purpose, I consolidated first-assigned patents issued to entities affiliated with the same parent. Sources for information relating to employee numbers and manufacturing operations include: company annual reports, company website, or the Hoover's company database. Employees include both technical and non-technical employees. These methods may still have overlooked some parent-subsidiary relationships.

99 Specifically, among all patents issued to Israeli filers from 2000 to 2015 , the following patent classes were designated most frequently: (I) multiplex communications $(5.93$ percent of all patents issued to Israeli filers); (2) drugs, bio-affecting and body-treating compositions (5.83 percent); (3) surgery (4.23 percent); (4) image analysis (3.47 percent); (5) telecommunications (3.09 percent); (6) multicomputer data transfer ( 3.08 percent); ( 7 pulse or digital communications ( 2.87 percent); (8) database and file management (2.87 percent); (9) memory (electrical computers) (2.79 percent); and (Io) error detection (2.48 percent). Author's calculations, based on USPTO, Extended Year Set, Utility Patent Report, Patenting by Geographic Origin (State and Country)-Breakout by Technology Class, https://www.uspto. gov/web/offices/ac/ido/oeip/taf/stcteca/regions_stcl_gd.htm (last visited Jan. 4, 2018) [hereinafter USPTO, Patenting by Geographic Origin-Breakout by Technology Class]. 
Figure II. Type Distribution of Identified First-Named Assignees of USPTO Patents Issued to Israeli Filers (2000 to 2015)

Entity Type

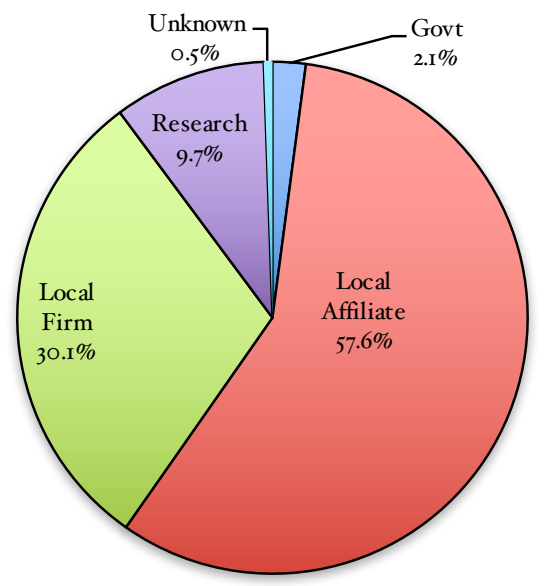

Industry Type

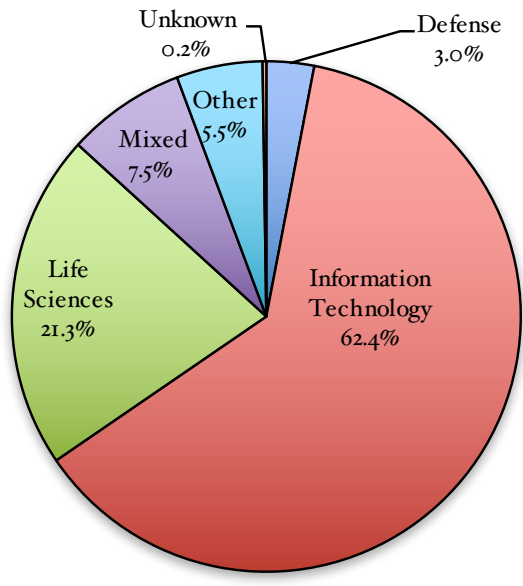

Source: Author's calculations, based on USPTO, Patenting by Geographic OriginBreakout by Organization, supra note 96.

Notes: I obtained data on assignees' entity and industry type, and any parent-subsidiary relationship, by consulting the website and annual report (if available) of each entity, or the Hoover's company database. In some cases, additional information relating to entity type was obtained by reviewing a sample of the entity's patents. For purposes of computing percentages, parents and subsidiaries were treated as a single entity (even if they were listed separately as patent filers in the USPTO data). For my methodology in identifying parent-subsidiary relationships, see supra note 98 and accompanying text. The "Mixed" category refers to entities engaged in both IT and life sciences activities (in almost all cases, these are academic research institutions).

We can observe further detail by examining more closely the top 15 firstnamed assignees of USPTO patents issued to Israeli filers from 2000 to 2015. Collectively these assignees represent 29 percent of all patents issued to Israeli filers during this period. ${ }^{10 \circ}$ Leading assignees include a mix of academic research institutions, local firms, and local affiliates of foreign firms. With the exception of HP and IBM, all foreign parents maintain R\&D expenditures in excess of $\mathrm{I} 2$ percent of sales. ${ }^{\text {Ior }}$ These assignees mostly provide R\&D inputs for the ICT sector, with additional significant representation in the life sciences and medical device markets. As reflected by employee numbers (for operations in Israel only), these entities are small to medium-size entities that, with some exceptions, lack significant local manufacturing capacities. This $R \& D$ focus obviously characterizes the $R \& D$ centers maintained by

100 Author's calculations, based on USPTO, Patenting by Geographic Origin-Breakout by Organization, supra note 96; USPTO, Utility Patents Report, supra note 22.

101 Author's calculations based on 2015 annual SEC filings for each company. 
large foreign corporations (which, with the exception of Intel, do not maintain production facilities in Israel) and the technology transfer entities of academic research institutions. Israeli universities, which (as shown above) represent almost Io percent of USPTO patents issued to Israeli filers from 2000 to 2015 , are especially vigorous patentees: in 2015, three of its universities were ranked among the top roo university patentees at the USPTO. ${ }^{102}$

Table I. First-Named Assignees of USPTO Patents Issued to Israeli Filers (Top 15, 2000 to 2015)

\begin{tabular}{|c|c|c|c|c|c|c|c|}
\hline Assignee & $\begin{array}{l}\text { Entity } \\
\text { Type }\end{array}$ & $\begin{array}{l}\text { Industry } \\
\text { Type }^{103}\end{array}$ & $\begin{array}{l}\text { Employees } \\
\text { in Israel }^{104}\end{array}$ & $\begin{array}{l}\text { Significant } \\
\text { Mfg. } \\
\text { Facilities in } \\
\text { Israel }\end{array}$ & $\begin{array}{l}\text { First-Assigned } \\
\text { Patents Issued } \\
\text { to Israeli Filers } \\
(2000-2015)\end{array}$ & $\begin{array}{l}\text { Percent of } \\
\text { Patents Issued } \\
\text { to Israeli Filers } \\
(2000-2015)^{105}\end{array}$ & $\begin{array}{l}\text { R\&D } \\
\text { Intensity } \\
(2015)^{106}\end{array}$ \\
\hline IBM & LA & ICT & 1,336 & $\mathrm{~N}$ & $\mathrm{I}, 497$ & $5.50 \%$ & $6.42 \%$ \\
\hline Intel & LA & ICT (Semi) & 8,826 & $\mathrm{Y}$ & $\mathrm{I}, \mathrm{I} 94$ & $4.39 \%$ & $21.91 \%$ \\
\hline HP & LA & ICT & $\mathrm{I}, 830$ & $\mathrm{~N}$ & 654 & $2.40 \%$ & $3.38 \%$ \\
\hline Marvell & LA & ICT (Semi) & 970 & $\mathrm{~N}$ & $6 \mathrm{II}$ & $2.24 \%$ & $38.68 \%$ \\
\hline SanDisk $^{107}$ & LA & ICT & 562 & $\mathrm{~N}$ & 483 & I. $77 \%$ & $15.87 \%$ \\
\hline $\begin{array}{l}\text { Yeda R\&D } \\
\text { (Weizmann } \\
\text { Institute) }\end{array}$ & $\mathrm{R}$ & ICT, LS & 654 & $\mathrm{~N}$ & 477 & $\mathrm{I} .75 \%$ & $\mathrm{n} / \mathrm{a}$ \\
\hline Tel Aviv Univ. & $\mathrm{R}$ & ICT, LS & $>2,200$ & $\mathrm{~N}$ & 409 & I. $50 \%$ & $\mathrm{n} / \mathrm{a}$ \\
\hline $\begin{array}{l}\text { Yissum R\&D } \\
\text { (Hebrew Univ.) }\end{array}$ & $\mathrm{R}$ & ICT, LS & I,OOO & $\mathrm{N}$ & 356 & I. $31 \%$ & $\mathrm{n} / \mathrm{a}$ \\
\hline Teva Pharm. & $\mathrm{LF}$ & LS & 6,967 & $\mathrm{Y}$ & $34 \mathrm{I}$ & $1.25 \%$ & $7.76 \%$ \\
\hline Cisco & LA & ICT & $>\mathrm{I}, \mathrm{OOO} \mathrm{O}^{\mathrm{10} 8}$ & $\mathrm{~N}$ & 329 & $\mathrm{I} .2 \mathrm{I} \%$ & $12.63 \%$ \\
\hline $\begin{array}{l}\text { Applied } \\
\text { Materials }\end{array}$ & LA & ICT (Semi) & I,OOO & $\mathrm{Y}$ & 325 & I.19\% & $15.02 \%$ \\
\hline $\begin{array}{l}\text { Technion } \\
\text { Foundation }\end{array}$ & $\mathrm{R}$ & ICT, LS & 620 & $\mathrm{~N}$ & 321 & I.I $8 \%$ & $\mathrm{n} / \mathrm{a}$ \\
\hline Broadcom & LA & ICT (Semi) & 278 & $\mathrm{~N}$ & 320 & I.18\% & $15.37 \%$ \\
\hline
\end{tabular}

102 See National Academy of Inventors, Top ioo Worldwide Universities Granted U.S. Utility Patents (2015).

103 "Semi" indicates that the company has significant business in some part of the semiconductor industry.

104 Employees refer to technical and non-technical employees. In the case of technology transfer entities of academic research institutions, employees refer to number of research faculty at the university, as stated on the university's website.

105 This refers to the percentage constituted by (I) identified first-assigned patents issued to Israeli filers from 2000 to 2015 out of (2) all USPTO patents issued to Israeli filers during that period.

$106 \mathrm{R} \& \mathrm{D}$ intensity is not applicable or not available in the case of research entities and private companies.

107 In May 2016, SanDisk was acquired by Western Digital. See Press Release, SanDisk, Western Digital Completes Acquisition of SanDisk, Creating a Global Leader in Storage Technology (May I2, 20I6), https://www.sandisk.com/about/media-center/press-releases/2016/western-digital-completes-acquisition-of-sandisk-creating-a-global-leader-in-storage-technology.

108 See Gwen Ackerman, Cisco to Buy Israel's Leaba Semiconductor for About \$320 Million, Bloomberg (Mar. 2, 20I6), https://www.bloomberg.com/news/articles/2016-03-02/cisco-said-to-agree-to-buy-israel-sleaba-semiconductor (stating that there are "over Iooo" employees at Cisco Israel). 


\begin{tabular}{|c|c|c|c|c|c|c|c|}
\hline 472 & \multicolumn{5}{|c|}{ The Criterion fournal on Innovation } & \multicolumn{2}{|c|}{$[$ Vol. $2: 429$} \\
\hline Assignee & $\begin{array}{l}\text { Entity } \\
\text { Type }\end{array}$ & $\begin{array}{l}\text { Industry } \\
\text { Type }\end{array}$ & $\begin{array}{l}\text { Employees } \\
\text { in Israel }\end{array}$ & $\begin{array}{l}\text { Significant } \\
\text { Mfg. } \\
\text { Facilities in } \\
\text { Israel }\end{array}$ & $\begin{array}{l}\text { First-Assigned } \\
\text { Patents Issued } \\
\text { to Israeli Filers } \\
(2000-2015)\end{array}$ & $\begin{array}{l}\text { Percent of } \\
\text { Patents Issued } \\
\text { to Israeli Filers } \\
(2000-2015)\end{array}$ & $\begin{array}{l}\mathrm{R} \& \mathrm{D} \\
\text { Intensity } \\
(2015)\end{array}$ \\
\hline $\begin{array}{l}\text { Iscar } \\
\text { (Berkshire } \\
\text { Hathaway) }\end{array}$ & $\mathrm{LA}^{\mathrm{109}}$ & $\begin{array}{l}\text { Other } \\
\text { (precision } \\
\text { tools) }\end{array}$ & 3,000 & $\mathrm{Y}$ & $25 \mathrm{I}$ & $0.92 \%$ & $\mathrm{n} / \mathrm{a}$ \\
\hline $\begin{array}{l}\text { Biosense } \\
\text { (Johnson \& } \\
\text { Johnson) }\end{array}$ & LA & $\begin{array}{l}\text { LS (medical } \\
\text { device) }\end{array}$ & 200 & $\mathrm{~N}$ & 234 & $0.86 \%$ & $\mathrm{I} 2.91 \%$ \\
\hline
\end{tabular}

Legend: LA = Local affiliate of foreign firm; TT = technology transfer office of academic research institution; LF = local firm; ICT = information and communications technology; LS = life sciences; $\mathrm{G}=$ government/military.

Sources: USPTO, Patenting by Geographic Origin-Breakout by Organization, supra note 96; USPTO, Utility Patents Report, supra note 22.

Notes: I relied on USPTO data for all patent-related information. With respect to all other information, I searched the company's 2014 or 2015 annual report filed with the SEC. If the filing did not disclose information or the company was private, I relied on information in the Hoover's company's database or the company's website, except as otherwise indicated. Note that parent and subsidiaries were consolidated even if listed as separate filers in the USPTO data. Unless otherwise indicated, all information is current as of September 2016.

\section{ii. R\&D Affiliates}

Patenting data demonstrate the prominent role of local R\&D centers maintained by large multinational technology firms. Although these R\&D centers ( 264 in total according to a recent report ${ }^{\mathrm{II}}$ ) are affiliated with a foreign parent, they often, if not typically, represent local innovation by firms that had been acquired by the parent. ${ }^{\text {III }}$ Considering the top 15 foreign-owned R\&D centers in Israel based on total USPTO patents first-assigned to the center's parent (or affiliates) from 2000 to 2015 , I found that, with two exceptions, each parent had acquired several Israeli targets (ranging from 3 (HP) to as many as $\mathrm{I} 4$ (Microsoft)) during that period. ${ }^{\mathrm{II} 2}$ Based on patenting and other data (as shown above in some cases), it appears that these foreign-owned R\&D

109 Iscar is marked as "LA" because it was acquired by Berkshire Hathaway in 20I3. However, it might more appropriately be classified as "LF" because it is generally recognized as one of Israel's leading indigenous commercial enterprises. Additionally, I did not include R\&D intensity for Iscar because, although Berkshire Hathaway is publicly traded, its R\&D intensity would not be reflective of Iscar's activities because the parent is not a technology-focused company.

110 See Lemarchand, Leck \& Tash, supra note 63, at 39 (citing Israel Venture Capital Research Center, Israel Venture Capital Database, http://www.ivc-online.com/Products-and-Services/IVC-Database).

111 A UNESCO report finds that, for the period from I990 to 2010, "at least I360 distinct inventions" were transferred from Israeli companies to Israeli $R \& D$ affiliates of foreign parents as a result of acquisition or merger transactions. See Lemarchand, Leck \& TASH, supra note 63, at xv.

112 Data on acquisitions of Israeli firms were taken from Bureau van Dijk, Zephyr, https://www.bvdinfo. com/en-gb/our-products/data/specialist/zephyr [hereinafter Zephyr Database]; Thomson Reuters, SDC Platinum, Worldwide Mergers, Acquisitions and Alliances Database, https://financial.thomsonreuters.com/en/products/data-analytics/market-data/sdc-platinum-financial-securities.html [hereinafter Worldwide Mergers, Acquisitions and Alliances Database]; SEC filings; and company press releases. Specifically, I found that the "top I 5 " foreign parents acquired the following numbers of Israeli targets from 2000 to 20I5: IBM (II); Intel (8); HP (3); Marvell (4); SanDisk (3); Broadcom (9); Cisco (7); Applied 
centers employ relatively small numbers of personnel, usually do not operate production facilities (the most notable exception being Intel), and supply $\mathrm{R} \& \mathrm{D}$ inputs for the parent's global manufacturing and distribution operations. ${ }^{113}$ These centers have been responsible for key ICT innovations, such as the Pentium MMX and Centrino microprocessors developed at Intel's Israeli R\&D facility, ${ }^{\mathrm{II} 4}$ the USB flash memory storage technology, initially developed by MSystems, an Israeli startup acquired by SanDisk in 2006, ${ }^{115}$ and the ICQ instant messaging technology, developed by Mirabilis, an Israeli startup acquired by AOL in $1998 .{ }^{116}$

\section{Evaluation: The Role of U.S. Patents in Israel's Innovation Ecosystem}

The data presented above provide the foundation for a preliminary understanding of the functions played by U.S. patents in Israel's innovation economy, especially in the market segment occupied by the top I5 first-named assignees in the Israeli USPTO population from 2000 to 2015 . There appear to be three functions, each corresponding to a different type of expropriation risk at different points on the technology supply chain. First, USPTO patents mitigate expropriation risks that might frustrate transactions between Israeli holders of R\&D inputs and third-party (typically, foreign) holders of commercialization inputs. This applies most clearly in the case of Israeli research universities engaged in technology transfer in the IT and, principally, life sciences markets. Second, USPTO patents mitigate expropriation risks that might discourage corporate-control transactions that enable local $\mathrm{R} \& \mathrm{D}$ firms to permanently access a larger foreign firm's commercialization infrastructure through an acquisition transaction. Third, USPTO patents mitigate expropriation risks that arise once an Israeli firm distributes into the U.S. market products and services that embody its technological innovations.

\section{i. Outsourcing Hazards}

The USPTO infrastructure might mitigate outsourcing hazards to the extent it enables Israeli firms and research institutions to safely deliver technology assets to foreign partners, which then embed those technologies into products and services for distribution in the U.S. market. Israeli firms often lack

\footnotetext{
Materials (3); Microsoft (I4); Apple (4); EMC (8); Qualcomm (5); Johnson \& Johnson (Biosense) (I); Berkshire Hathaway (Iscar) (I).

113 For methodology and sources, see supra note 98.

114 See David Shamah, Israel Inside: A History of Intel's R\&D in Israel, ZDNet (Aug. 28, 20I2), http://www.zdnet.com/article/israel-inside-a-history-of-intels-r-d-in-israel/.

115 See Lucas Mearian, Why Israel Is a Hotbed for Flash Storage Innovation, Computerworld (May I7, 20I2), https://www.networkworld.com/article/218864I/network-storage/why-israel-is-a-hotbed-for-flashstorage-innovation.html.

116 See AOL Buys Israel's Mirabilis, InTERNEtNews (June 8, 1998), http://www.internetnews.com/bus-news/ article.php/2IOII/AOL+Buys+Israels+Mirabilis.htm.
} 
adequate (or, in the case of a research institution, any) production, distribution, and marketing capacities to achieve worldwide distribution rapidly or efficiently. Hence, those entities outsource downstream functions to thirdparty partners that excel in those functions. The obstacle to these transactions is that the third-party partner poses an expropriation threat to the Israeli firm that holds a valuable $\mathrm{R} \& \mathrm{D}$ input, either at the time of negotiation or during the course of a business relationship. Consider the Weizmann Institute, Israel's most prolific academic patentee (from 2000 to 2015 , it received more USPTO patents than all but 26 U.S. universities ${ }^{117}$ ) and one of the world's most commercially successful technology transfer entities. ${ }^{\text {II8 }}$ Weizmann's technology transfer entity would naturally be reluctant to enter into a testing, production, and distribution agreement with a pharmaceutical firm if it could not protect its intellectual assets with some combination of contract and patent rights. Equipped with a U.S. patent portfolio (consisting of 477 USPTO patents issued from 2000 to 2015 ), Weizmann can enter into commercialization transactions with corporate partners and extract returns on the institution's intellectual capital. For example, in 1987 Weizmann licensed to Teva Pharmaceuticals patents relating to the Copaxone treatment for multiple sclerosis, which ultimately earned $\$ 4$ billion in sales in $2014 .{ }^{\mathrm{II}}$

\section{ii. Acquisition and Distribution Hazards}

The USPTO infrastructure might mitigate transactional hazards that would otherwise discourage foreign firms from acquiring local Israeli firms, which are then typically converted into R\&D centers. As noted above, large foreign (mostly U.S.) technology firms regularly acquire Israel startups, ${ }^{120}$ which then continue to acquire USPTO patents as an R\&D subsidiary of the parent firm. From 2000 to 2015 , the top 15 first-named foreign-firm assignees of USPTO patents issued to Israeli filers acquired 88 Israeli firms (in documented transactions); in 30 percent of those transactions, the target held USPTO patents at the time of the acquisition. ${ }^{21} \mathrm{~A}$ USPTO patent portfolio mitigates an internal transactional hazard that might otherwise discourage foreign firms from acquiring and maintaining R\&D operations in Israel. Namely, the founder and senior executives of the acquired firm, or any other employee of the post-acquisition R\&D entity, might pose a post-acquisition expropriation

\footnotetext{
117 Author's calculations, based on USPTO, Patenting by Geographic Origin-Breakout by Organization, supra note 96.

118 See Gali Weinreb, Yeda Earns \$50-IooM Annually, GLobes (July 28, 2013), http://www.globes.co.il/en/ article-1000865926.

119 See id.

120 See supra note II2 and accompanying text.

121 Author's calculations, based on Zephyr Database, supra note II2 (for acquisitions data); Worldwide Mergers, Acquisitions and Alliances Database, supra note II2 (for acquisitions data); USPTO, Patenting by Geographic Origin-Breakout by Organization, supra note 96 (for patenting data).
} 
threat to the foreign firm. Patents can mitigate the expropriation threats that are posed by departing employees and cannot be satisfactorily addressed by contractual limitations on employee mobility. ${ }^{122}$ Given the parent's USPTO patent portfolio, presumably combined (as is typical) with a pre-assignment and nondisclosure agreement, ${ }^{123}$ the target founders and executives, or post-acquisition employees, can more credibly commit against using the firm's R\&D assets to found a competing startup or join a competing firm. ${ }^{124}$ Additionally, consistent with the function typically attributed to patents, any patents acquired by the target firm, or the $R \& D$ center into which the target firm is converted following acquisition, mitigate distribution hazards in the target U.S. market and promote the parent's ability to capture returns on the amounts expended in the acquisition transaction and the amounts it continuously invests in its R\&D operations in Israel. The same function is at play in the case of integrated Israeli firms (most notably, Teva Pharmaceuticals ${ }^{125}$ ) in the biopharmaceutical and medical devices markets that couple patent-protected R\&D with in-house production and distribution capacities. ${ }^{226}$

\section{B. Case Study II: Taiwan}

Like Israel, Taiwan's rise to prominence is remarkable given its small size: despite having land territory approximately equal to the Netherlands and a population about a fifth of that of Japan, it is the third-largest center for the production of information technology equipment, the fourth-largest source

122 See Jonathan M. Barnett \& Ted Sichelman, Revisiting Employee Mobility in Innovation Markets (USC Law Legal Studies Paper, No. I6-15, 2016). In Israel, practitioners report that courts rarely enforce noncompete agreements. See Heather A. Stone, Yael Dolev \& Yael Ben Naim, In the Start-Up Nation Where Know-How Is Everywhere-Is It Protected?, Paper Presented at the American Bar Association 2014 International Labor and Law Committee Midyear Meeting (Apr. I6, 2014), http://www.gkh-law.com/ wp-content/uploads/2014/o9/In-the-Start-Up-Nation-Where-Know.pdf.

123 Non-disclosure and non-use agreements are typically enforced by Israeli courts. Non-solicitation agreements are typically not enforced. See Stone, Dolev \& Naim, supra note I22, at 6-7, 20.

124 For an example of how a leading Taiwanese chip firm brought patent litigation in a U.S. court (and the ITC) to address patent infringement claims relating to the departure of employees to a competitor, see Part IV.B.3.i. A related explanation is that the patent may signal to potential investors the quality of a startup's claimed technological innovation. Assuming a patent is costly to obtain and defend in court, the patent can be used to screen out false claims of technological novelty and support a higher valuation of the startup from investors. For a theoretical model and supporting evidence from samples of Israeli startups, see Annamaria Conti, Jerry Thursby \& Marie C. Thursby, Patents as Signals for Startup Financing (NBER Working Paper, No. 19191, 2013); Gili Greenberg, Small Firms, Big Patents? Estimating Patent Value Using Data on Israeli Startups' Financing Rounds, Io Eur. MGMt. Rev. I83 (20I3).

125 Although Teva is the world's largest generic pharmaceutical firm, it maintains a significant proprietary drug business: as of 2015 , it constitutes 5 I percent of Teva's total revenues. See Teva Pharm., Annual Report for the Fiscal Year Ended December 3I, 2015 (SEC Form 2O-F), at 7, 20 (filed Feb. II, 2OI6).

126 Based on USPTO data, some Israeli medical device firms maintain significant USPTO patent portfolios and couple $\mathrm{R} \& \mathrm{D}$ capacities with in-house manufacturing and distribution functions. An example is Medinol, a first-named assignee of 77 USPTO patents from 2000 to 2015 . USPTO, Patenting by Geographic Origin-Breakout by Organization, supra note 96. Medinol developed a leading type of stent for cardiovascular treatment and maintains both R\&D and manufacturing operations. See NIR Legacy of Innovation, Medinol, http://www.medinol.com/us/nir-legacy-innovation/ (describing stent innovation); About Us, Medinol, www.medinol.com/us (describing in-house R\&D and manufacturing operations). 
of semiconductor chips, ${ }^{\mathrm{I} 27}$ and, as noted, currently the top country-level recipient of U.S. patents on a per capita basis. Even more dramatic than Israel, Taiwan has enjoyed a remarkable jump in economic development: in I980, it had a per capita GDP of $\$ 2,368$, as compared with $\$ 8,336$ for Italy; in 2014 , it had a per capita GDP of $\$ 22,598$, as compared with $\$ 35,823$ for Italy. ${ }^{128}$ Like Israel, Taiwan suffers from a selective disadvantage in the form of a small domestic market, which has always compelled Taiwan to enter into trade relationships with large foreign markets. Unlike Israel, Taiwan initially enjoyed a selective advantage in the form of low labor costs, which it used to enter global technology markets by offering manufacturing and assembly services to U.S. and Japanese firms in the PC and consumer electronics markets. By the mid-I990s, Taiwan was a leading producer of multiple categories of consumer electronics, a position it largely continues to hold today (even though Taiwanese firms have mostly moved operations to other countries). ${ }^{129}$ As Taiwan developed, it lost its labor-cost advantage. Taiwanese firms responded by developing "foundry" services for chip design firms and integrated chip manufacturers and entering into the chip design and electronics component design segments. ${ }^{130}$ The result is a mixed technology economy that supports "lower-value" contract manufacturing by OEMs, "intermediate-value" foundry production for foreign and domestic chip design firms, and "higher-value" technology development in the chip design and electronics components markets. ${ }^{13 \mathrm{I}}$ Below I show how patents, together with limited government intervention, appear to support this market structure.

\section{Background}

The rise of Taiwan as a technology leader has its roots in three policy actions by the Taiwanese government. First, in 1973, the Taiwanese government established the Industrial Technology Research Institute (ITRI), a research institute tasked with pursuing industrial priorities for the economy. ${ }^{132}$ ITRI

127 See Bor-Shiuan Cheng, Dragon Appearing in the Field: The Legend of the Semiconductor Industry in Tairwan, in Terence Tsai \& Bor-Shiuan Cheng, The Silicon Dragon: High-Tech Industry in Taiwan i, 8 (Edward Elgar 2006) [hereinafter Tsai \& Cheng, The Silicon Dragon].

128 IMF, World Economic Outlook Database, supra note 65. Figures expressed in current prices.

129 See Kenneth L. Kraemer, Jason Dedrick, Chin-Yeong Hwang \& Chee-Sing Yap, Entrepreneurship, Flexibility and Policy Coordination: Taiwan's Computer Industry, I2 INFo. SoC'Y 215 (2006).

130 See Shin-Horng Chen, Global Production Networks and Information Technology: The Case of Taiwan, 9 Indus. \& Innovation 249 (2002); Chintay Shih, Kung Wang \& Yi-Ling Wei, Hsinchu, Tairwan: Asia's Pioneering High-Tech Park, in Making IT: The Rise of Asia in High Tech ioi, IO2-o9 (Henry S. Rowen, Marguerite Gong Hancock \& William F. Miller eds., Stanford Univ. Press 2007).

131 See John A. Mathews \& Dong-Sung Cho, Tiger Technology: The Creation of a SemiconducTOR Industry In East Asia 272-73 (Cambridge Univ. Press I999).

132 See Chao-Tung Wen \& Jun-Ming Chen, Tairwan: Linked-Based Clusters of Innovation-The Case of Taiwan's IT Industry, in Global Clusters of Innovation, supra note 92, at 222, 224; Dan Breznitz, Development, Flexibility and R\&D Performance in the Tairwanese IT Industry: Capability Creation and the Effects of State-Industry Coevolution, I4 Indus. Corp. Change 153, I59 (2005) [hereinafter Breznitz, Development, Flexibility and RむDD Performance]. 
(including its subsidiary, the Electronics Research and Service Organization (ERSO)) surveyed foreign markets for technologies required to establish a semiconductor industry in Taiwan and reduce the country's reliance on commodity contracting work for branded electronics firms. ${ }^{133}$ In some cases, ERSO obtained licenses to patents, or purchased patents covering, targeted technologies, which it transferred to Taiwanese firms for commercial development. ${ }^{\mathrm{I} 4}$ Second, in $\mathrm{I} 980$, the government established the Hsinchu industrial park, where technology firms were given tax and other incentives to set up operations. ${ }^{\mathrm{I} 5}$ Third, in 1987 , 1992, and 1994 , the government enacted reforms to its local patent system to increase protection, lengthen the patent term and improve enforcement. ${ }^{136}$ Although my analysis focuses on the effect of the U.S. patent system on Taiwanese firms, this fact is relevant insofar as it signaled an institutional commitment to IP rights in a country that had previously been known for piracy.

\section{Patent Data: Window into Firm and Market Characteristics}

Data on the first-named assignees of patents issued to Taiwanese filers provide a window into the primary types of entities in Taiwan's innovation economy. For this purpose, I examined a pool consisting of first-named assignees identified by the USPTO in its country-based breakdown of utility patent grants (which includes all such assignees other than entities that received fewer than five USPTO patents during 1969 to 2015$).{ }^{137}$ This "identified first-named assignees" pool represents a significant majority (75 percent) of USPTO patents issued to Taiwanese filers during 2000 to

\footnotetext{
133 See Cheng, supra note I27, at I2-I3. ITRI continues to engage in these types of activities today. See Industrial Technology Research Institute [ITRI], 20I4 Annual Report (2OI4); Po Young Chu, Yu Ling Lin, Hsing Hwa Hsiung \& Tzu Yar Liu, Intellectual Capital: An Empirical Study of ITRI, 73 TecH. Forecasting \& Social Change 886 (2006); John A. Mathews, A Silicon Valley of the East: Creating Taiwan's Semiconductor Industry, 39 Calif. Mgmt. Rev. 26, 3I-32 (I997).

134 See Mathews \& Cho, supra note 13I, at I90; Kraemer, supra note I29, at 230; An-Chi Tung, Tairwan's Semiconductor Industry: What the State Did and Did Not Do, 5 Rev. Dev. Econ. 266 (200I); Soo-Hung Terence Tsai \& Chang-Hui Zhou, Science Parks in Taiwan: HSIP and TSIP, in Tsai \& Cheng, The Silicon Dragon, supra note 127 , at 50, 58 (observing that ERSO used foreign technology as the basis for internal research, or reverse engineered existing technology, which, upon completion, it then transferred to private industry for commercial application). For further discussion, see Wen \& Chen, supra note I32.

135 See Mathews, supra note 133 , at 30-3I.

136 For detailed discussion, see Chih-Hai Yang, The Effects of Strengthening Intellectual Property Rights in NIEs: Evidence from Taiwan's 1994 Patent Reform, 26 ConTemp. ECON. Pol'y 259 (1994).

137 USPTO, Patenting by Geographic Origin-Breakout by Organization, supra note 96. This five-patent limitation appears to be the reason why the pool of patents for which the USPTO identifies first-named assignees (as well as individually owned patents that do not name any such assignee) is smaller than the total pool of patents issued to Taiwanese filers as reported elsewhere by the USPTO. See USPTO, Utility Patents Report, supra note 22.
} 
$20155^{13^{8}}$ If we consolidate parents and subsidiaries within this assignee pool, ${ }^{139}$ there are I,325 unique identified first-named assignees of patents issued to Taiwanese filers during this period. The assignee population falls into three major categories: (I) ITRI, the government research institute mentioned above; (2) academic research institutions; and (3) local technology firms. In turn, local technology firms fall into three broad categories: (I) a handful of large foundries that provide chip manufacturing services to other firms; (2) a handful of large branded consumer electronics manufacturers; and (3) a large population of differently sized entities that specialize in the design, manufacture, and assembly of PCs, smartphones, and electronics components. This industry type distribution is consistent with data on the patent classes favored by Taiwanese filers, who, from 2000 to 2015 , patented most heavily in patent classes relating to semiconductors, electrical systems, and information storage. ${ }^{140}$

The charts below show, from 2000 to 2015 , (I) the percentage that each entity type represents out of the total pool of identified first-named assignees of USPTO patents issued to Taiwanese filers; and (2) the percentage that each industry type represents out of that same pool.

\footnotetext{
138 Author's calculations, based on USPTO, Patenting by Geographic Origin-Breakout by Organization, supra note 96 (providing information on assignees, with country breakdown), and USPTO, Utility Patents Report, supra note 22 (providing information on utility patent grants, with country breakdown). 139 For my methodology in identifying parent-subsidiary relationships, see supra note 98 and accompanying text.

140 Specifically, Taiwanese filers patented most heavily in the following classes: (I) semiconductor device manufacturing ( 8.38 percent of all patents issued to Taiwanese filers from 2000 to 2015); (2) solid-state devices (for example, transistors) (8.02 percent); (3) electrical connectors (4.64 percent); (4) electrical systems and devices (4.I2 percent); (5) computer graphics processing (3.56 percent); (6) illumination (3.06 percent); (7) information storage (I.79 percent); (8) liquid crystal cells (I.72 percent); (9) optical systems and elements (I.66 percent); and (IO) television (I.47 percent). Author's calculations, based on USPTO, Patenting by Geographic Origin-Breakout by Technology Class, supra note 99.
} 
Figure I2. Type Distribution of Identified First-Named Assignees of USPTO Patents Issued to Taiwanese Filers (2000 to 2015)
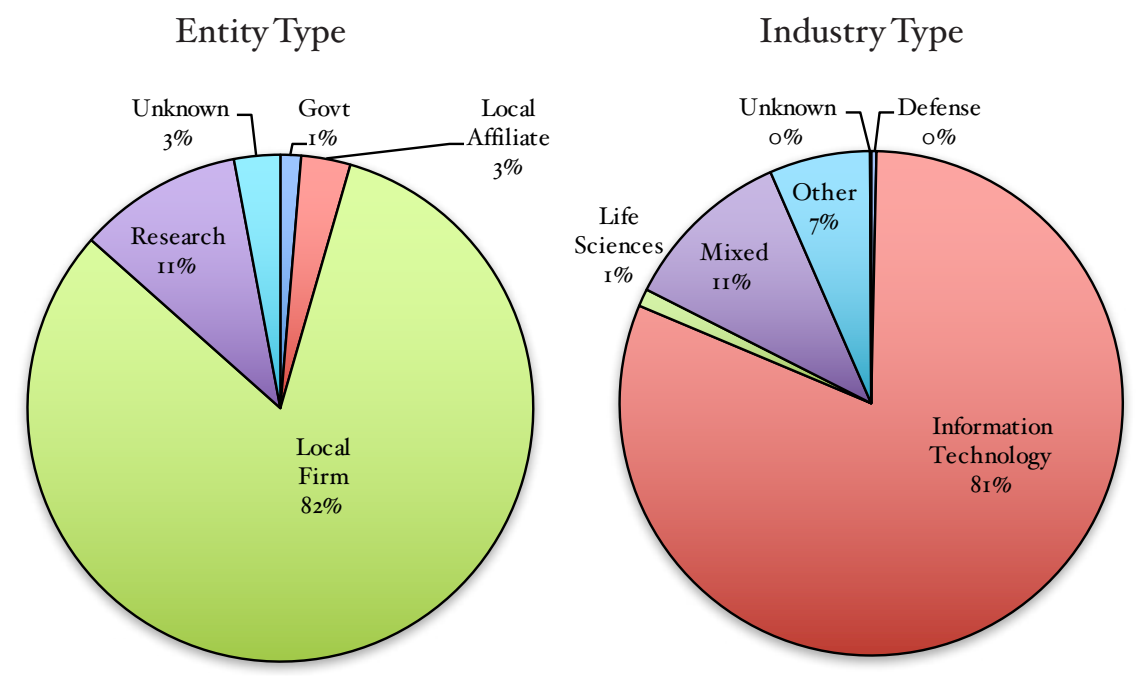

Source: Author's calculations, based on USPTO, Patenting by Geographic Origin-Breakout by Organization, supra note 96.

Notes: I obtained names of assignees through the USPTO database. I then obtained data on assignees' entity and industry type, and any parent-subsidiary relationship, by consulting the website and annual report (if available) of each entity, the Hoover's company database, or the EMIS database. In some cases, additional information relating to entity type was obtained by reviewing a sample of the entity's patents. For purposes of computing percentages, parents and subsidiaries were treated as a single entity (even if they were listed separately as patent filers in the USPTO data). For my methodology in identifying parent-subsidiary relationships, see supra note 98. The "Mixed" category refers to entities engaged in both information technology and life sciences activities (in almost all cases, these are academic research institutions).

We can observe further detail by examining the top i5 first-named assignees of USPTO patents issued to Taiwanese inventors from 2000 to 2015. Collectively these assignees hold 37 percent of all USPTO patents issued to Taiwanese filers during this period. ${ }^{\mathrm{II}}{ }^{\mathrm{I}}$ Within this group, five entities account for 24.6 percent of all patents issued to Taiwanese filers from 2000 to $2015^{142}$ : (I) Hon Hai Precision Co. (also known as Foxconn), the largest electronics components assembler in the world; (2) ITRI, the government research and commercialization institute described above; (3) TSMC and (4) UMC, the world's largest semiconductor foundries; and (5) AU Optronics, the world's leading manufacturer of liquid crystal displays (LCDs). The remainder of the "top I5" group is constituted by hardware firms and the Taiwan university

141 Author's calculations, based on USPTO, Patenting by Geographic Origin-Breakout by Organization, supra note 96; USPTO, Utility Patents Report, supra note 22.

142 See sources cited in supra note I4I. 
system. Taiwanese universities have recently performed especially strongly at the USPTO: in 2015, five of its universities were among the top roo university patentees at the USPTO. ${ }^{143}$

As noted earlier, Taiwan's IP trade deficit raises concerns over the quality of Taiwan's patenting activities, ${ }^{144}$ although Taiwan's improving success ratio, which now matches U.S. filers, ${ }^{145}$ allays those concerns to a certain extent. Other commentators have expressed similar concerns, ${ }^{146}$ although this seems to be based on an equation of patent quality with product innovation, rather than the process innovation in which Taiwanese firms often excel. To address this concern further, I calculated the R\&D intensities of the 15 Taiwanese non-governmental entities that were first-assigned the most USPTO patents from 2000 to 2015 . All firms that are primarily involved in chip fabrication and chip design exhibit high $\mathrm{R} \& \mathrm{D}$ intensity rates (as of 2015), in excess of 7 percent in the case of the foundries and in excess of 20 percent in the case of the chip design firms. This compares favorably with other Asian IT hardware firms such as Panasonic (5.93 percent), Samsung (7.40 percent), Sony (5.65 percent), Toshiba (5.07 percent), and LG (4.2I percent), and, in the case of the chip design firms, compares favorably with U.S. semiconductor firms such as Intel (2I.9I percent) and Broadcom (I5.37 percent). ${ }^{147}$ Hon Hai and three IT hardware firms show low R\&D intensity rates compared with other Asian IT hardware firms, which may therefore account in part for Taiwan's IP trade deficit. ${ }^{14^{8}}$ In the aggregate, these data suggest, consistent with the trajectory of Taiwanese inventors' success ratios, that, at least in recent years, Taiwanese patents are reflective to a significant extent of underlying innovative capacity and activity.

\footnotetext{
143 See Press Release, Academy of Inventors, Top Ioo Worldwide Universities Granted U.S. Utility Patents (July I2, 2015). Financial Results for the Year Ended March 3I, 2015, at 5 (2015) [hereinafter Panasonic 2015 Annual Report]; Samsung Electronics Co., Consolidated Financial Statements of Samsung Electronics Co. Ltd. and Subsidiaries 6, 66 (2016) [hereinafter Samsung 20i5 Annual Report]; Sony Corp., Annual Report for the Fiscal Year Ended March 3I, 2016 (SEC Form 20-F), at 6 (filed June I7, 20I6) [hereinafter Sony 20I5-I6 Annual Report]; Toshiba, Annual Report 20I5: Financial Review 20, 52 (2015) [hereinafter Toshiba 20I5 Annual Report]; LG Electronics, Consolidated Financial Statements, December 3I, 20I4 AND 20I5, at 4 (2OI6) [hereinafter LG 2OI4-I5 Annual Report]; Intel Corp., Annual Report for the Fiscal Year Ended December 26, 2015 (SEC Form IO-K), at 40 (filed Feb. I2, 20I6) [hereinafter Intel 2015 Annual Report]; Avago Techs. Ltd., Annual Report for the Fiscal Year Ended November I, 2015 (SEC Form IO-K), at 5I (filed Dec. 17, 2015) [hereinafter Avago 2015 Annual Report]. Note that Broadcom was acquired by Avago in February 2016.

148 In companies that exhibit a combination of high patenting rates and low R\&D intensities (compared with industry peers), there is a legitimate concern that patenting is being driven in significant part by an effort to reduce licensing rates paid to external technology suppliers or, relatedly, to deter third-party infringement suits.
} 


\begin{tabular}{|c|c|c|c|c|c|c|c|}
\hline 2017$]$ & \multicolumn{6}{|c|}{ Patent Tigers } & $48 \mathrm{I}$ \\
\hline \multicolumn{8}{|c|}{$\begin{array}{l}\text { Table 2. First-Named Assignees of USPTO Patents } \\
\text { Issued to Taiwanese Filers (Top I5, 2000 to 2015) }\end{array}$} \\
\hline Assignee & $\begin{array}{l}\text { Entity } \\
\text { Type }\end{array}$ & $\begin{array}{l}\text { Industry } \\
\text { Type }\end{array}$ & $\begin{array}{l}\text { Employees } \\
\text { (Total) }^{149}\end{array}$ & $\begin{array}{l}\text { Mfg } \\
\text { Facilities } \\
\text { in Taiwan? }\end{array}$ & $\begin{array}{l}\text { First Assigned } \\
\text { Patents Issued to } \\
\text { Taiwanese Filers } \\
(2000-2015)\end{array}$ & $\begin{array}{l}\text { Percent of } \\
\text { Patents Issued to } \\
\text { Taiwanese Filers } \\
(2000-2015)^{150}\end{array}$ & $\begin{array}{l}\text { R\&D } \\
\text { Intensity } \\
(2015)\end{array}$ \\
\hline $\begin{array}{l}\text { Taiwan } \\
\text { Semiconductor } \\
\text { Mfg. }\end{array}$ & $\mathrm{LF}$ & $\operatorname{ICT}(\mathrm{F})$ & $\begin{array}{l}43,591 \\
(39,386 \\
\text { TW only) }\end{array}$ & $\mathrm{Y}$ & 9,437 & $7.93 \%$ & $7.77 \%$ \\
\hline $\begin{array}{l}\text { Hon Hai } \\
\text { Precision }\end{array}$ & LF & $\operatorname{ICT}(\mathrm{H})$ & $\begin{array}{l}830,174 \\
\text { (est. 46,ooo } \\
\text { TW only) }\end{array}$ & $\mathrm{Y}$ & 8,324 & $6.99 \%$ & I.I $.7 \%$ \\
\hline $\begin{array}{l}\text { Indus.Tech. } \\
\text { Research Inst. }\end{array}$ & G & ICT & $\begin{array}{l}\text { II,I49 } \\
\text { (TW only) }\end{array}$ & $\mathrm{Y}$ & 5,128 & $4.31 \%$ & $\mathrm{n} / \mathrm{a}$ \\
\hline $\begin{array}{l}\text { United } \\
\text { Microelecs. }\end{array}$ & $\mathrm{LF}$ & $\operatorname{ICT}(\mathrm{F})$ & 18,538 & $\mathrm{Y}$ & 3,262 & $2.74 \%$ & $8.4 \mathrm{I} \%$ \\
\hline AU Optronics & $\mathrm{LF}$ & $\operatorname{ICT}(\mathrm{H})$ & $\begin{array}{l}67,833 \\
(24,155 \\
\text { TW only) }\end{array}$ & $\mathrm{Y}$ & 3,106 & $2.61 \%$ & $2.47 \%$ \\
\hline MediaTek & $\mathrm{LF}$ & $\mathrm{ICT}(\mathrm{CD})$ & 15,754 & $\mathrm{Y}$ & $2,54 \mathrm{I}$ & $2.13 \%$ & $23.23 \%$ \\
\hline Macronix Int'l & $\mathrm{LF}$ & $\mathrm{ICT}(\mathrm{CD})$ & $4,22 \mathrm{I}$ & $\mathrm{Y}$ & 2,129 & $\mathrm{I} .79 \%$ & $23.73 \%$ \\
\hline Innolux & $\mathrm{LF}$ & $\operatorname{ICT}(\mathrm{H})$ & 80,645 & $\mathrm{Y}$ & $\mathrm{I}, 475$ & I. $24 \%$ & $3.96 \%$ \\
\hline Wistron Corp. & LF & $\operatorname{ICT}(\mathrm{H})$ & $\mathrm{n} / \mathrm{a}^{152}$ & $\mathrm{Y}$ & $\mathrm{I}, 44^{8}$ & $\mathrm{I} .22 \%$ & $2.15 \%$ \\
\hline Delta Elecs. & LF & $\operatorname{ICT}(\mathrm{H})$ & $\mathrm{n} / \mathrm{a}^{153}$ & $\mathrm{Y}$ & $\mathrm{I}, 395$ & I.I $7 \%$ & $7.11 \%$ \\
\hline $\begin{array}{l}\text { Univ. Sys. of } \\
\text { Taiwan } \\
\text { 154 }\end{array}$ & $\mathrm{R}$ & M & $\begin{array}{l}2,321 \\
(T W \text { only })^{155}\end{array}$ & $\mathrm{n} / \mathrm{a}$ & $\mathrm{I}, 317$ & I.II $\%$ & $\mathrm{n} / \mathrm{a}$ \\
\hline Via Techs. & $\mathrm{LF}$ & $\mathrm{ICT}(\mathrm{CD})$ & $\mathrm{I}, 728$ & $\mathrm{Y}$ & 1,262 & 1.06\% & $30.69 \%$ \\
\hline $\begin{array}{l}\text { Republic of } \\
\text { China }\end{array}$ & G & M & $\mathrm{n} / \mathrm{a}$ & $\mathrm{n} / \mathrm{a}$ & $\mathrm{I}, \mathrm{I} 83$ & $0.99 \%$ & $\mathrm{n} / \mathrm{a}$ \\
\hline Inventec & $\mathrm{LF}$ & $\operatorname{ICT}(\mathrm{H})$ & $49, \mathrm{II} 8$ & $\mathrm{Y}$ & 952 & $0.80 \%$ & $2.23 \%$ \\
\hline $\begin{array}{l}\text { Realtek } \\
\text { Semiconductor }\end{array}$ & $\mathrm{LF}$ & ICT (CD) & 2,465 & $\mathrm{Y}$ & 927 & $0.78 \%$ & $28.04 \%$ \\
\hline
\end{tabular}

149 Employees refer to technical and non-technical employees. In the case of technology transfer entities of academic research institutions, employees refer to the number of research faculty at the university. Note that I list total employee figures for each company, rather than only employees in Taiwan, because it was typically not possible to reliably determine employees in Taiwan only.

150 This refers to the percentage constituted by (I) identified first-assigned patents issued to Taiwanese filers from 2000 to 2015 out of (2) all USPTO patents issued to Taiwanese filers during that period.

151 As of 20I4, based on Lorraine Luk, Hon Hai Beefs Up Hiring in Tairwan, WALl ST. J. (Mar. IO, 2014), https://blogs.wsj.com/digits/20I4/o3/ro/hon-hai-beefs-up-hiring-in-taiwan/.

152 This figure could not be reliably determined due to a discrepancy between the Hoover's company database, which indicates 6,074 employees, and the company website, which indicates over 60,000 employees worldwide.

153 This figure could not be reliably determined due to a discrepancy between the Hoover's company database, which indicates 5,868 employees, and the company website, which indicates over 60,000 employees worldwide.

154 This is an entity that integrates certain resources of four research universities in Taiwan. It appears to operate as a technology transfer entity for these universities.

155 This refers to the number of instructors as of 20II. See Analysis of Research Achievements, UnIVERSITY SYSTEM OF TAIWAN, http://ust.edu.tw/new/english/eor.htm. 
Legend: $\mathrm{G}$ = governmental research entity; $\mathrm{LF}=$ local firm; $\mathrm{R}=$ research institution; $\mathrm{ICT}=$ information and communications technology; $\mathrm{F}=$ foundry; $\mathrm{CD}=$ chip design (fabless); $\mathrm{H}=$ hardware (incl. assembler); $\mathrm{M}=$ mixed.

Sources: USPTO, Patenting by Geographic Origin-Breakout by Organization, supra note 96; USPTO, Utility Patents Report, supra note 22.

Notes: I relied on USPTO data for all patent-related information. With respect to all other information, I searched the company's 2014 or 2015 annual report. If the filing did not disclose information or the company was private, I relied on information in the Hoover's company database or the company's website, except as otherwise indicated. It was not possible in most cases to determine a firm's employees located only in Taiwan; hence worldwide employee figures are provided. In the limited number of cases in which there was reliable information on a firm's employees located in Taiwan, that information was included in parentheses as shown above. Note that parent and subsidiaries were consolidated under the parent's name even if listed as separate filers in the USPTO data. Unless otherwise indicated, all information is current as of September 2016.

\section{Evaluation: The Role of USPTO Patents in Tairwan's Innovation Economy}

The data presented above provide a foundation for a preliminary understanding of the functions of USPTO patents in Taiwan's innovation ecosystem, especially in the market segment occupied by the top 15 first-named assignees in the Taiwanese USPTO population from 2000 to 2015 . There appear to be three primary functions, each corresponding to a different expropriation risk. First, as is discussed in the existing literature, patent licenses mitigated "insourcing hazards" and thereby enabled Taiwanese entities to initially secure access to foreign technology from Japanese and U.S. firms, which was used to enter, and subsequently undertake $\mathrm{R} \& \mathrm{D}$ in, the electronics component and chip production markets. ${ }^{156}$ Relatedly, ITRI obtained licenses to secure foreign technology for applied research purposes, which it then transmitted to local firms (especially foundries). Second, patents mitigate outsourcing hazards and thereby enable "fabless" chip design firms (that is, firms without production capacities) to enter into mutually profitable production relationships with Taiwanese foundries. Third, patents enable Taiwanese foundries and other firms to protect innovations (principally process innovations) in chip fabrication and other IT production segments and earn a return on their R\&D investments. To structure the analysis, I focus on semiconductor design and manufacturing. ${ }^{157}$

\footnotetext{
156 See Sturgeon \& Lee, supra note 70, at 51. For discussion of a Taiwanese firm's innovations in electronic component design (specifically, scanners), see SAXENIAN, supra note 4 , at I66. On the importance of technology in-licensing transactions in fostering the development of the Taiwanese TFT-LCD (display panel) industry, which was then followed by $\mathrm{R} \& \mathrm{D}$ and patenting by the Taiwanese partner firms, see Mei-Chih Hu, Industry and Knowledge Evolution: The Case of Taiwan's Flat Panel Display Industry, in Tarwan's Economic Transformation in Evolutionary Perspective: Entrepreneurship, Innovation Systems and Government 155 (Fu-Lai Tony Yu ed., Nova Science 2007).

157 My discussion identifies key transactions in which patent licensing facilitated the voluntary transmission of knowledge inputs from U.S., European, and Japanese firms to Taiwanese firms, which in turn seeded indigenous R\&D in the Taiwanese chip production and design industries. Given the widespread piracy that characterized Taiwan at least until the enactment of patent reforms starting in the late I980s, see supra note 136 and accompanying text, a fuller study of Taiwan's innovation economy would consider
} 


\begin{tabular}{lll}
\hline 2017$]$ & Patent Tigers & 483 \\
\hline
\end{tabular}

\section{i. The Foundry Model}

Patents enabled Taiwan's initial insourcing of technological knowledge from foreign firms, primarily through ITRI. Two technology transfers in particular laid the foundation for Taiwan's foundries and subsequent leadership in semiconductor production.

First, in 1976, RCA and ITRI entered into a license agreement permitting ITRI to make use of RCA's semiconductor process technology. ${ }^{158}$ Specifically, the license enabled IRTI to enjoy access to RCA's patented complementary metal-oxide-silicon (CMOS) technologies (plus related know-how and training provided by RCA). On that basis, ERSO constructed a pilot IC production facility. ${ }^{159}$ Thereafter, ITRI spun off the facility to a newly formed private entity, United Microelectronics Corporation (UMC). ${ }^{60}$ Second, in approximately 1983, ITRI licensed Very Large Scale Integration (VLSI) technology from a small California-based firm ${ }^{161}$ ERSO later transferred its rights in VLSI technology to a standalone foundry, the Taiwan Semiconductor Manufacturing Corporation (TSMC), established in 1986 as part of a joint venture with Philips. ${ }^{162}$ Philips contributed cash, chip fabrication patents, and Philips' rights under cross-licensing agreements with semiconductor producers. ${ }^{163}$

TSMC pioneered the "pure play" foundry model (as contrasted with the vertically integrated model used by Intel and other incumbents in the chip industry), in which standalone production services are provided to chip design firms that lack the capital required to construct a fabrication facility or to integrated chip manufacturers in need of additional capacity. ${ }^{164}$ Within about a decade after its founding in 1986 , TSMC constituted the world's largest stand-alone chip foundry, ${ }^{165}$ and, as of 20I4, Taiwanese firms constituted approximately $7 \mathrm{I}$ percent of the worldwide foundry market. ${ }^{166}$ Taiwanese foundries have developed process and equipment innovations in

\footnotetext{
whether other segments may have benefited from the involuntary transmission of knowledge inputs held by foreign firms.

158 See SAXENian, supra note 4, at I40; Shih, Wang \& Wei, supra note I30, at IIO; Tung, supra note I34.

159 See Mathews \& Cho, supra note I3I; Wen \& Chen, supra note 132, at 225; Shih, Wang \& Wei, supra note I30, at IIO; Tung, supra note I34; Mathews, supra note I33, at 26, 34.

160 See Saxenian, supra note 4, at I4O; Wen \& Chen, supra note I32, at 225; Shih, Wang \& Wei, supra note I3O, at IIO.

161 See Mathews \& Cho, supra note I3I, at 169; Mathews, supra note 133, at 26, 36; Sung Gul Hong, The Political Economy of Industrial Policy in East Asia 54 (Edward Elgar 1997) (noting a joint research agreement between ERSO and Vitelic to develop VLSI technology).

162 See Hong, supra note I6I, at 55; Tung, supra note I34.

163 See Mathews \& Cho, supra note I3I, at I60, 259; Mathews, supra note I33, at 26, 36. For further description of the agreement and subsequent amendments, see Taiwan Semiconductor Mfg. Co., Annual Report for the Fiscal Year Ended December 3I, 2004 (SEC Form 2O-F), at 48 (filed May 16, 2005). For the amended agreement, see $i d$. Exhibit 4.8.

164 See Breznitz, Development, Flexibility and R\&D Performance, supra note 132, at 159.

165 See Mathews \& Cho, supra note I3I, at I79.

166 R.O.C. (Taiwan) National Development Council, Taiwan Statistical Data Book i2 (2O15).
} 
chip manufacturing ${ }^{167}$ which they have sought to protect through patent portfolios as is typical in the chip industry worldwide. ${ }^{168}$ Those portfolios protect the foundries' $\mathrm{R} \& \mathrm{D}$ investments against expropriation by competitors and departing employees. This is not merely theoretical: in 2003 and 2004, TSMC initiated patent and trade secret litigations against SMIC, a Chinese chip manufacturer, which involved in part the alleged disclosure of TSMC's trade secrets by employees that had departed for SMIC and the alleged use by SMIC of TSMC's patented technology. ${ }^{169}$ Interestingly, these litigations were brought in U.S. federal court ${ }^{170}$ and at the International Trade Commission $^{171}$ (as noted earlier, a U.S. administrative entity) on the basis of TSMC's USPTO portfolio.

Although Taiwanese foundries are located at the mid-stream production stage in the supply chain, it is clear that the firms must make significant $R \& D$ investments to reduce production costs and achieve performance targets in the competition for chip design clients. ${ }^{172}$ The foundries' R\&D efforts are reflected both in their R\&D intensity ( $R \& D$ expenditures as a percentage of total revenues) and patenting behavior. As of 2015, TSMC's R\&D intensity was 7.77 percent and UMC's R\&D intensity was 8.4 percent, ${ }^{173}$ which compares favorably with leading Asian IT hardware firms such as Samsung (7.4 percent), Sony (5.65 percent), Toshiba (5.07 percent), and LG (4.2I percent). ${ }^{174}$ Although it falls below the R\&D intensity of leading U.S. semiconductor firms such as Intel (2I.9I percent) and Broadcom (I5.37 percent), ${ }^{175}$ those firms have chip design capacities, which are located further upstream on the supply chain and may therefore demand greater $\mathrm{R} \& \mathrm{D}$ expenditures.

\footnotetext{
167 See Douglas Fuller, Akintunde Akinwande \& Charles Sodini, Leading, Following or Cooked Goose? Innovation Successes and Failures in Tairwan's Electronics Industry, Io Indus. \& INNOvaTion I79, I83 (2003).

168 On patenting practices in the semiconductor industry, see Stefan Tamme, Stephen Schott, Dogan Gunes, Jeffrey Wallace, Richard Boadway, Frank Razavi \& Marc Pépin, Trends and Opportunities in Semiconductor Licensing, Semiconductor Licensing Trends, Dec. 2013 , at 216.

169 See Sumner Lemon, China's SMIC Settles Lawsuits with TMIC, InfoWorld (Jan. 3I, 2005), https://www.infoworld.com/article/2669319/computer-hardware/china-s-smic-settles-lawsuits-with-tsmc. html.

170 See Taiwan Semiconductor Mfg. Co. v. Semiconductor Mfg. Int'l Corp., No. C-03-576rMMC, 2004 WL 5212448 (N.D. Cal. Apr. 2I, 2004).

171 See Notice of Investigation, Certain Semiconductor Devices and Products Containing Same, Inv. No. 337-TA-525, 69 Fed. Reg. 56,459 (Sept. 21, 2004).

172 See Shin-Horng Chen, Pei-Chang Wen \& Meng-Chun liu, Trends in Public and Private Investments in ICT R\&D in Taiwan 26 (20II); Tamme, Schott, Gunes, Wallace, Boadway, Razavi \& Pépin, supra note I68, at 220; Fuller, Akinwande \& Sodini, supra note I67, at I8I-82.

173 Author's calculations, based on Taiwan Semiconductor Mfg. Co., Annual Report for the Fiscal Year Ended December 3I, 2015 (SEC Form 2O-F), at 26 (filed Apr. II, 2016); United Microelectronics Corp., Annual Report for the Fiscal Year Ended December 31, 2015 (SEC Form 2O-F), at 5I-52 (filed Apr. I8, 20I6).

174 Author's calculations, based on SAMsung 2015 Annual Report, supra note I47, at 6, 66; Sony 2015-16 Annual Report, supra note I47, at 6; Toshiba 2015 ANnUAL Report, supra note I47, at 20, 52; LG 20I4-15 ANNUAL Report, supra note I47, at 4.

175 Author's calculations, based on Intel 2015 Annual Report, supra note 147, at 40; Avago 2015 Annual Report, supra note I47, at $5 \mathrm{I}$.
} 


\begin{tabular}{lll}
\hline 2017$] \quad$ Patent Tigers & 485 \\
\hline
\end{tabular}

\section{ii. Fabless Chip Design}

The foundry model represented an important organizational innovation that enabled smaller chip design firms to enter the market without having to fund the billions of dollars ${ }^{176}$ required to construct a chip fabrication facility (a "fab"). As such, it has had a second favorable effect on Taiwan's innovation economy by supporting domestic IC design houses that would not otherwise have had access to manufacturing facilities. ${ }^{177}$ Within one year of the founding of TSMC (in 1987), the number of chip design firms in Taiwan increased from 4 to $40,{ }^{178}$ and, as of 20I4, there were approximately 245 such firms based in Taiwan. ${ }^{179}$ The result is a disaggregated market cluster of small to medium-sized chip design firms, complemented by firms that specialize in other parts of the chip testing, packaging, and production process. ${ }^{180}$ As of 2015, Taiwanese firms represented approximately i 8 percent of the worldwide fabless industry, constituting the largest chip design source after the United States. ${ }^{81}$

Patents appear to have promoted this development in two primary respects. First, patents mediate in-licensing and joint venture relationships between U.S. and Taiwanese chip design firms, which can then use those licenses to cultivate independent design capacities. ${ }^{82}$ Second, patents have mediated production relationships between Taiwanese chip design firms and foundries. Specifically, patents resolve a two-way expropriation dilemma. On the one hand, design firms must disclose extensive information to the foundry in the course of the production process. ${ }^{183}$ This raises (and design firms have reportedly expressed) concerns that the foundry will expropriate those designs by providing them to a competing firm. ${ }^{184}$ On the other hand, as UMC (a leading Taiwanese foundry) stated in a litigation before the ITC, the foundry must disclose elements of its process technology to the design

\footnotetext{
176 As of 2015, estimated construction cost for a new "fab" was \$5 to \$ro billion. See Semiconductor Industry Association, Beyond Borders: The Global Semiconductor Value Chain 22 (20i5) [hereinafter SIA, BEYOND Borders].

177 See Mathews \& Cho, supra note I3I, at 30, 38 fig.I.Io, 89, I78; Shin-Horng Chen, Global Production Networks and Information Technology: The Case of Taiwan, 9 Indus. \& InNovation 249-65 (2002); Mathews, supra note $\mathrm{I} 33$, at 36-37.

178 See Tung, supra note I34, at 272.

179 SIA, BEYOND Borders, supra note I76, at I9-20.

180 See Chen, Wen \& Liu, supra note 172 , at 26.

181 See SIA, Beyond Borders, supra note i76, at ir fig.8.

182 For a description of some of these partnerships, see SAXENIAN, supra note 4, at I79-80. For a discussion of the same and how Taiwanese firms subsequently secured dominant market shares in certain chip market segments, see Douglas B. Fuller, Moving Along the Electronics Value Chain: Taiwan in the Global Economy, in Global TaIwan, supra note 70, at 137, I45-46.

183 See Chen, Wen \& LiU, supra note I72, at 33.

184 See Shin-Horng Chen, Global Production Networks and Information Technology: The Case of Taiwan, 9 Indus. \& InNOvation 259-6o (2002); Shahid Yusuf, Competitiveness Through Technological Advances Under Global Production Networking, in Global Production Networking and Technological Change in East Asia i, Io (Shahid Yusuf, M. Anjum Altaf \& Kaoru Nabeshima eds., World Bank 2004).
} 
firm in order to facilitate coordination between the customer's circuit design and the foundry's manufacturing process. ${ }^{185}$ This poses expropriation risk to the extent that the design firm has existing or potential chip manufacturing capacity (or that its employees can move to a firm with chip manufacturing capacity). Patents mitigate both sides of this expropriation dilemma by protecting the design firm against expropriation by the foundry, while, in certain cases, protecting the foundry from expropriation by the design firm.

\section{B. Summing Up: The International Chip Supply Chain}

Patents perform different functions in the innovation economies of Israel and Taiwan: whereas patents appear to most often protect product innovation in Israel, they appear to most often protect process innovation in Taiwan. In both cases, patents enable firms to reap the benefits of comparative advantage by supplying the global IT market with the supply-chain functions in which those firms excel. This allocation of supply-chain functions yields an efficiency gain by minimizing the costs of sourcing $R \& D$ inputs, assembling commercialization inputs, and delivering the final product to the end user. The relationship between patents, comparative advantage, and supply-chain design can be illustrated by reference to the Marvell Technology Group and Taiwan Semiconductor Manufacturing Corporation (TSMC). ${ }^{186}$

Marvell is a large semiconductor firm that maintains its operational headquarters and an R\&D center in Silicon Valley while operating additional R\&D centers in China, Israel, Singapore, and Switzerland. Its Israeli R\&D center is a significant enterprise (consisting of approximately I,200 employees out of a total global workforce of 7,163 employees as of $\left.2015^{187}\right)$ that has been developed in part through the acquisitions of Israeli firms: (I) Galileo (acquired in 200I for \$2.7 billion); (2) RadLan Technologies (acquired in 2003 for $\$ 49.7$ million and additional equity); (3) DSPC (acquired in 2006 for $\$ 600$ million); and (4) Iamba Networks (acquired in 2008 for \$IO million). ${ }^{88}$

185 Certain Integrated Circuits, Processes for Making Same and Products Containing Same, Inv. No. 337-TA-450, USITC Pub. 3624, at 248-49 (Oct. 7, 2002) (testimony by UMC, Vice President for Field Engineering).

186 Unless otherwise indicated, all remaining information in this part is based on the 2015 annual reports of Hon Hai, HP, Marvell, and TSMC, as filed with the SEC, and, in the case of Hon Hai, as available on its website, Hon Hai Precision Industry Co., Ltd., Annual Report 2016 (20I7), http://www.foxconn.com/Files/annual_rpt_e/2or6_annual_rpt_e.pdf.

187 See David Shamah, Amazon to Buy Israeli Hardware Firm for \$35om, Times of Israel (Jan. 22, 2015), https://www.timesofisrael.com/sources-amazon-set-to-buy-israeli-hardware-firm-for-35om/ (estimating the number of employees at Marvell's Israeli facilities); Marvell Tech. Grp. Ltd., Annual Report for the Fiscal Year Ended January 3I, 2015 (SEC Form IO-K), at 36 (fiscal year ended Jan. 3I, 2015) (showing the total number of Marvell employees).

188 See Nikhil Deogun \& Molly Williams, Marvell Technology Agrees to Buy Israel’s Galileo in \$2.7 Billion Deal, WAll St. J. (Oct. I7, 2000), https://www.wsj.com/articles/SB9717446541757I2989; Press Release, Marvell Technology Group, Ltd., Marvell Acquires RADLAN Computer Communications Ltd., A Leading Provider of Embedded Networking Software (Feb. 6, 2003), https://www.marvell.com/company/ news/pressDetail.do?releaseID=333; Shmulik Shelah, Intel Sells DSPC for \$6oom 7 Years After Paying \$1.6b, 
As a "fabless" firm, Marvell has no independently owned fabrication facilities and contracts for chip production services, primarily with TSMC. ${ }^{189}$ As of 2015, the firm exhibits an exceptionally high R\&D intensity (38.68 percent), which exceeds even Intel (2I.9I percent) and Google (I6.38 percent). ${ }^{190}$ That $\mathrm{R} \& \mathrm{D}$ investment has resulted in a significant patent portfolio, consisting of approximately 5,543 U.S. patents as of 2015 (of which 83 percent were issued to U.S. inventors, II percent to Israeli inventors, and the remainder to inventors in other countries, ${ }^{\text {III }}$ all presumably working at Marvell's R\&D centers). That USPTO patent portfolio ameliorates expropriation risks that could frustrate Marvell's ability to monetize its R\&D assets through a supply chain structure that is disaggregated over multiple countries but ultimately targets the U.S. market. At the same time, TSMC's large patent portfolio (consisting of approximately I0,I6I U.S. patents as of $2015^{192}$ ) provides some protection against expropriation of TSMC's process technologies, whether by competitors or departing employees.

The map below depicts a "sample" supply chain in which four firmsMarvell, TSMC, Hon Hai, and HP-must interact and exchange knowledge assets in order to deliver an IT good to the target U.S. market. At each sensitive point of knowledge exchange, USPTO patents, presumably in conjunction with licensing and employment agreements, regulate information flow and allow the supply chain to move forward efficiently. In simplified form, the sequence consists of four information-intensive transactions. First, in the upstream market for $\mathrm{R} \& \mathrm{D}$ inputs, the patent portfolio regulates information flow between Marvell and its R\&D centers in Israel, Switzerland, Singapore, and China, whose employees may pose an internal expropriation

GlOBes (June 27, 2006), http://www.globes.co.il/en/article-Ioooro6803; Erez Wollberg, Marvell Acquires Start-Up iamba for \$1om, Globes (Nov. 26, 2008), http://www.globes.co.il/en/article-I000401660.

189 See Marvell Tech. Grp. Ltd., Annual Report for the Fiscal Year Ended January 30, 2016 (SEC Form IO-K), at 8, 25, 37 (filed July 2I, 20I6) [hereinafter Marvell 2015 Annual Report].

190 Author's calculations based on id. at 29; Intel 2015 Annual Report, supra note I47, at 40; Alphabet Inc. \& Google Inc., Annual Report for the Fiscal Year Ended December 31, 2015 (SEC Form IO-K), at 37 (filed Feb. II, 20I6).

191 Author's calculations, based on (I) USPTO data and (2) information disclosed in Marvell's 20I5 annual report concerning the location of its R\&D centers. See USPTO, Patenting by Geographic OriginBreakout by Organization, supra note 96; Marvell 2015 Annual Report, supra note 189, at 32. For purposes of calculating the firm's USPTO patents, I included any patent assigned to Marvell (and the acquired companies mentioned above) as a first-named assignee from 1995 through 2015 . This assumption is overinclusive to the extent that Marvell did not maintain in force all of the patents assigned to it during that time, but underinclusive given that I do not take into account any patents acquired by Marvell from third parties.

192 Author's calculations, based on USPTO, Patenting by Geographic Origin-Breakout by Organization, supra note 96. For purposes of calculating the firm's USPTO patents, I included any patent assigned to TSMC as a first-named assignee from 1995 through 2015 . This assumption is overinclusive to the extent that TSMC did not maintain in force all of the USPTO patents assigned to it during that time, but underinclusive given that I do not take into account any patents acquired by TSMC from third parties. Based on TSMC's 2015 annual report, it holds almost 20,000 patents issued by other countries; these too may mitigate expropriation risk following the reasoning set forth above. See Technology Leadership, Tarwan Semiconductor Manufacturing Co.: 2015 TSMC Annual Report, http://www.tsmc.com/download/ir/ annualReports/2015/english/e_5_2.html. 
threat. Second, in the intermediate market for chip production services, the patent portfolio regulates information flow between Marvell and TSMC (and, by implication, TSMC's other customers). Additionally, TSMC's patent portfolio enables it to overcome expropriation risks and reveal design inputs and process technologies to its customers and employees. Third, in the intermediate market for assembly services, Marvell's patent portfolio protects against expropriation risk from OEMs such as Hon Hai (which operates an offshore production facility in China in the supply chain shown below), ${ }^{193}$ which receive the chips from Marvell for use in devices assembled for foreign branded manufacturers (in the sample supply chain, HP) located in the U.S. market.

Figure I3. International Semiconductor Supply Chain (Simplified)

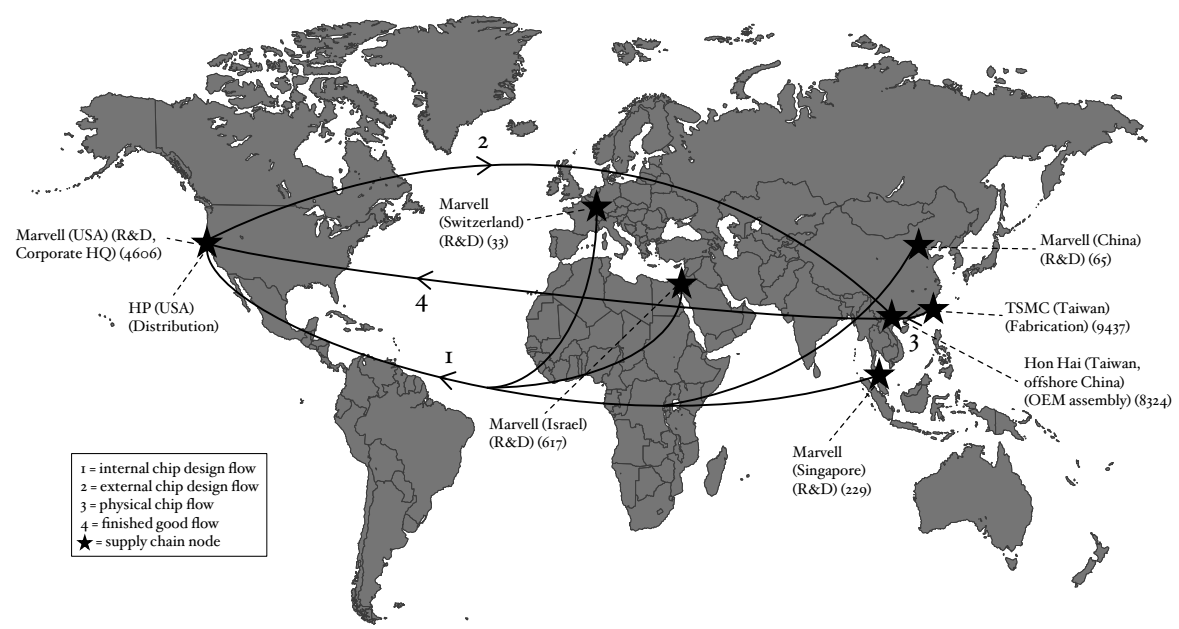

Sources: USPTO, Patenting by Geographic Origin-Breakout by Organization, supra note 96; Marvell 2015 Annual Report, supra note 189; Map Pins Infographic, Microsoft Office Templates, https://templates.office.com/en-us/Maps.

Notes: Number in parentheses following each entity indicates the number of USPTO patents first-assigned to that entity from 2000 to 2015 . In the case of patents assigned to Marvell, I assume that any such patent that is issued to an inventor resident in a foreign country was patented by an employee at Marvell's R\&D center in that country. For simplicity, some steps in an actual semiconductor supply chain have been omitted.

193 Certainly, a U.S. patent only protects against expropriation risk at a production facility in a weak-IP regime such as China to the extent that it can potentially block importation into the U.S. market. 


\begin{tabular}{lll}
\hline $20 \mathrm{I} 7 \mathrm{Patent}$ Tigers & 489 \\
\hline & Conclusion
\end{tabular}

It is often argued that the patent system stands in tension with growth and innovation in developing countries. ${ }^{194}$ This article identifies a notable exception. In the case of at least three emerging markets, extensive use of the U.S. patent system appears to have supported innovation and been accompanied by significant movement up the growth ladder. Within a few decades, Israel, Korea, and Taiwan have invested heavily in cultivating a rich stock of human and intellectual capital and obtaining USPTO patents to extract a return from those investments. The result is impressive: as of 2015 , these relatively small countries are (together with Japan) the most intensive foreign users of the U.S. patent system on a per capita and per GDP basis. Although further empirical inquiry is warranted, the result does not seem accidental. Existing theory and empirics support the view that patents are especially valuable as entry tools for smaller R\&D-intensive firms that lack the capital and expertise to establish the production and distribution infrastructure required to execute the commercialization process. The "patent tigers" phenomenon suggests that this effect extends from the firm level to the country level. Jurisdictions with rich intellectual capital but limited domestic markets can extract returns from $\mathrm{R} \& \mathrm{D}$ investments through transactions with third parties that facilitate the pathway to larger foreign markets. The property rights umbrella supplied by the U.S. patent system provides a critical tool to achieve that objective.

194 See supra note I and accompanying text. 